\title{
Variation in Microbial Community Profiles and Their Energy Metabolism Predictions Under the Influence of Pure and Mixed Fertilizer in Soil Microcosms
}

\section{Mohsin Gulzar Barq}

Quaid-i-Azam University Islamabad: Quaid-i-Azam University https://orcid.org/0000-0001-6213-1135

\section{Muhammad Mabashar Hassan}

Quaid-i-Azam University Islamabad: Quaid-i-Azam University

\section{Nicola Lorenz}

The Ohio State University

\section{Noshaba Hassan Malik}

Quaid-i-Azam University Islamabad: Quaid-i-Azam University

\section{Richard Dick}

The Ohio State University

Naeem Ali ( $\nabla$ naeemali2611@gmail.com )

Quaid-i-Azam University Islamabad: Quaid-i-Azam University

\section{Research Article}

Keywords: NPK fertilizers, paddy soil, microcosm, high throughput sequencing, PICRUSt, methane metabolism

Posted Date: March 19th, 2021

DOl: https://doi.org/10.21203/rs.3.rs-319529/v1

License: (c) (1) This work is licensed under a Creative Commons Attribution 4.0 International License. Read Full License 
1 Variation in microbial community profiles and their energy metabolism predictions under the influence of pure

2 and mixed fertilizer in soil microcosms

3 Mohsin Gulzar Barq ${ }^{1}$, Muhammad Mubashar Hassan ${ }^{1}$,Nicola Lorenz ${ }^{2}$, Noshaba Hassan Malik ${ }^{1}$, Richard P. Dick ${ }^{2}$,

$4 \quad$ Naeem $\mathrm{Ali}^{1,3^{*}}$

$5 \quad{ }^{1}$ Department of Microbiology, Quaid-i-Azam University, Islamabad, 45320, Pakistan.

$6 \quad{ }^{2}$ School of Environment and Natural Resources, 2021 Coffey Road, The Ohio State University, Columbus, OH 43210-

$7 \quad 1085$, USA.

$8 \quad{ }^{3}$ Biodesign Swette Center for Environmental Biotechnology, Arizona State University, Tempe Arizona (AZ), USA.

$9 *$ Corresponding author:

10 Tel.: +92-051 9064-3194

11 E-mail address: naeemali2611@gmail.com

12

13

14

15

16

17

18

19

20

21

22 


\section{Abstract}

24

The impact of environmental perturbations (e.g., nitrogen $(\mathrm{N})$, phosphorus $(\mathrm{P})$, potassium $(\mathrm{K})$ and rice straw $(\mathrm{Rs}))$ on the dynamics of soil bacterial and archaeal community are multifactor dependent and seeks more investigation concerning underlyig mechanisms. Current study was designed to establish the effect of pure and mixed fertilizers on microbial community profiles in paddy soil. A short-term microcosm based experiment was established in which each microcosm is amended with $\mathrm{N}$ as $\mathrm{C}\left(\mathrm{H}_{2} \mathrm{~N}\right)_{2} \mathrm{O}, \mathrm{P}$ and $\mathrm{K}$ as $\mathrm{KH}_{2} \mathrm{PO}_{4}, \mathrm{~K}$ as $\mathrm{KCl}$ and Rs with concentrations equivalent to $160 \mathrm{~kg} \mathrm{~N} \mathrm{ha}^{-1}, 60 \mathrm{~kg} \mathrm{P} \mathrm{ha}^{-1}, 130 \mathrm{~kg} \mathrm{~K} \mathrm{ha}^{-1}$ and $1 \%$ respectively. Soil $\mathrm{pH}$, electrical conductivity (EC), total C (TC), total nirtrogen $(\mathrm{TN})$, organic matter $(\mathrm{OM})$, available $\mathrm{K}(\mathrm{AK})$ and extractable $\mathrm{P}(\mathrm{EP})$ were evaluated. To understand the microbial community variation in soil and to predict their metabolic functions, a high throughput sequencing (HTS) approach of 16S rRNA gene along with phylogenetic investigation of communities by reconstruction of unobserved states (PICRUSt) was employed and analyzed. The results showed that microbial richness and diversity were increased under all amnendments compared to control. Proteobacteria, Actinobacteria and Firmicutes were dominant bacterial phyla. In all amendments, regarding relative abundance, Chloroflexi, Bacteroidetes and Verrucomicrobia showed positive while Actinobacteria, Acidobacteria and Gemmatimonadetes showed negative trends when compared with controlled observations. Thaumarchaeota and Euryarchaeota were dominant archaeal phyla and exhibited increasing and decreasing trends, respectively. The PICRUSt indicated microbial community shift significantly towards amino acid, carbohydrate, energy, and lipid metabolism while less towards glycan biosynthesis, synthesis of secondary metabolites, terpenoids and biodegradation. Regarding metabolism (methane metabolism), most and least responsive treatments were predicted to be KP and controls, respectively. These findings enhanced our understanding regarding soil quality, fertilizer composition and their impact on microbial diversity.

Keywords: NPK fertilizers, paddy soil, microcosm, high throughput sequencing, PICRUSt, methane metabolism

\section{Declarations:}

Funding: The current study was non-funded.

Conflicts of interest/Competing interests: We declare no Conflicts of interest/Competing interests.

Availability of data and material (data transparency): The datasets generated during and/or analyzed during the current study are available from the corresponding author on reasonable request. The sequencing data was submitted 
49 in the Sequence Read Archive (SRA) of NCBI (National Center for Biotechnology Information) under the BioProject

50 PRJNA627288 with accession numbers SAMN14661259 to SAMN14661276 and can be accessed.

51 Code availability (software application or custom code): We strongly believe that all data and materials as well as

52 software application comply with field standards.

53 Authors' contributions: Conceptualization: [Naeem Ali]; Methodology: [Mohsin Gulzar Barq, Muhammad

54 Mubashar Hassan]; Formal analysis and investigation: [Mohsin Gulzar Barq, Muhammad Mubashar Hassan]; Writing

55 - original draft preparation: [Mohsin Gulzar Barq]; Writing - review and editing: [Mohammad Mubashar Hassan,

56 Noshaba Hassan Malik]; Resources: [Richard Dick]; Supervision: [Naeem Ali].

57 Ethics approval (include appropriate approvals or waivers): No approval of research ethics committees was

58 required to accomplish the goals of this study because experimental work was conducted with an unregulated

59 invertebrate species.

60 Consent to participate (include appropriate statements): Not Applicable.

61 Consent for publication (include appropriate statements): Not Applicable.

62

63

64

65

66

67

68

69

70

71

72 
73

74

75

76

77

78

79

80

81

82

83

84

\section{Introduction}

Soil plays a complex and fundamental part in terrestrial ecosystem and microbial ecology by executing its biotic and abiotic processes that evolve over time [1]. The efficiency and sutainability of terrestrial agroecosystem is highly reliant on micobial diversity and physiology that vaires continuously with the nutrients' status [2,3]. The substantial role of soil microbiome in energy flow, nutrient cycling [4] and soil quality determinant is well documented [3]. The soil quality is often accompained with nutrient status and microbial community dynamics which make them vital parameters to interrogate in soil ecology studies. A minor shift in organic and inorganic content of soil may shift the microbial community dynamics and modify their underlying mechanisms [5-7] and ultimatley lead to varying yield and soil quality [8]. In this context, the relative abundance and role of specific microbes is considerably important [9].

The 16S rRNA based high-throughput sequencing (HTS) has been well established in recent years to study microbial community ecology dynamics in short and long term studies [10] thus making it an excellent method of choice.

The physicochemical and biological behaviour of paddy soil under flooded irrigation is quite different from upland soil $[11,12]$. The nutrient budget of paddy soil is dependent on supplementation of organic (e.g rice straw) and inorganic fertilizers e.g NPK respectively [7]. The role of paddy soils is very important concerning methane status and recycling which is one of the green house gases that has 25 times more ultravoilet (UV) retention capability in atmosphere compared to $\mathrm{CO}_{2}$ and paddy soilds are the major artificial sites of methanogenesis after natural wetlands. From environmental perspective, methanotrophs are more highlighted as consumers compared to methanogens as producers that are participating in biogeochemical cycling of $\mathrm{CH}_{4}$ in an antagonistic manner [13]. Typically, aerobic soil is the only biological sink for the oxidation of methane by methanotrophic bacteria sequestering about $6.0 \%$ in upland dry soils (i.e., forest and grasslands) and 10.0 to $30.0 \%$ in wetland soils [14, 15]. Globally, paddy soils contribute $15-20 \% \mathrm{CH}_{4}$ emission (25-100 Tg/year) which increased during rice cultivation seasons [16, 17]. It is predicted to be increased up to $50 \%$ (145 Tg/year) by 2025 due to growing demands of rice production and consumption. Thus it will lead to greater input of NPK fertilizers that may affect the energy metabolism of microbial communities turning soil into source of methane emission rather than sink [18-20]. However, the effect of inorganic fertilizers depends on the type, concentration, mode of application of fertilizers [21]. For instance, NPK fertilization and rice straw has been known to induce varying degree variations in soil physicochemical properties and microbial community dynamics [22-24] 
Though it is still unclear how microbial community dynamics transform with different sources of carbon (C), N, P and $\mathrm{K}$, since it fluctuates with multiple factors such as soil texture, $\mathrm{pH}, \mathrm{EC}, \mathrm{OM}$, availability of mineral nutrients and other accompanied microorganisms as well [25]. Considering the variability in type and application rate of fertilizers in paddy soil, it is vital to know the change in soil microbial community structure, function and chemistry that ultimately affect global methane burden. So, a microcosm-based experiment was established to investigate and predict the said question. The specific hypothesis of the study was to evaluate the effect of short-term supplementation of rice straw and NPK based fertilizers on the composition and relative abundance of bacterial and archaeal community in paddy soil. Additionally, PICRUSt derived functional profiles i-e energy metabolism of contributing microbial community can be predicted to estimate methane metabolism and there may be a correlation between dynamics of microbial communities and physicochemical factors.

\section{Materials and Methods}

\section{Experimental soil}

112 Soil samples (non-calcareous, silty clay loam, isohyperthermic Udic Hapludalfs) were acquired from a depth of 10$11320 \mathrm{~cm}$ in early August 2018 from the rice paddy field in Gujranwala, Pakistan $\left(32^{\circ} 19^{\prime} \mathrm{N}, 74^{\circ} 20^{\prime} \mathrm{E}\right)$. The area is $226 \mathrm{~m}$ 114 above sea level with hot semi-arid climate (BSh) [26]. The annual rainfall varies around $577 \mathrm{~mm}$ with average annual 115 temperature of $23.9{ }^{\circ} \mathrm{C}$. The field soil was transported to the experimental provision in a zipper bag to minimize contamination. The samples were air dried, sieved $(2 \mathrm{~mm})$ and stored at $-20{ }^{\circ} \mathrm{C}$ till further experimentation. Aseptic 117 conditions were maintained wherever necessary. The soil had a pH of 8.05 , TC $0.17 \%$ and TN $1.40 \%$.

\section{Microcosm Set-up and supplementation}

119 The microcosms were established using $2.2 \mathrm{~kg}$ soil slurry in $64 \mathrm{oz}$ polyethylene plastic pots $(20 \mathrm{~cm}$ height and $15 \mathrm{~cm}$ 120 diameter) and anaerobic conditions were created by flooding the soil with $3 \mathrm{~cm}$ of water. Each microcosm was planted 121 with a 26-day old nursery of Oryza sativa (var. super basmati). Excluding two controls and time zero sample, 15 122 different combinations were developed in triplicates using $\mathrm{N}$ (as urea), $\mathrm{P}$ and $\mathrm{K}$ (as $\mathrm{KH}_{2} \mathrm{PO}_{4}$ ), $\mathrm{K}$ (as $\mathrm{KCl}$ ) [27] and rice 123 straw (Table 1). All microcosms were amended accordingly with 50ml solution of each fertilizer (per $100 \mathrm{ml}: 0.23 \mathrm{~g}$

$124 \mathrm{~N}$ as urea, $0.087 \mathrm{~g} \mathrm{P}$ as $\mathrm{KH}_{2} \mathrm{PO}_{4}$ and $0.185 \mathrm{~g} \mathrm{~K}$ as $\mathrm{KCl}$ ). Additionally, concentrations of carrier ions were calculated as $1250.05 \mathrm{~g} \mathrm{~K}$ in $\mathrm{KH}_{2} \mathrm{PO}_{4}$ and $0.08 \mathrm{~g}$ Chloride $(\mathrm{Cl})$ in $\mathrm{KCl}$. The supplementation was done at day 0,5 and 30 as basal dressing and two top dressings. The two controls (with plant and without plant) were provided with the same conditions as that 
127 of samples but without any supplementation. These amendments were in accordance with common rice field 128 agriculture and correspond to per ha $160 \mathrm{~kg} \mathrm{~N}$ as urea, $60 \mathrm{~kg} \mathrm{P}$ as $\mathrm{KH}_{2} \mathrm{PO}_{4}, 130 \mathrm{~kg} \mathrm{~K}$ as KCl and $1 \%$ rice straw [28].

129 The constructed microcosms were placed at an average temperature of $20-25^{\circ} \mathrm{C}$ in a green house facility for 45 days 130 and the water level of $3 \mathrm{~cm}$ was maintained throughout that period. Soil samples were collected during vegetation 131 phase from each microcosm for further analysis.

\section{Soil Physicochemical Properties}

133 The soil moisture content was calculated following gravimetric method $[29,30]$ and represented as gravimetric water content (GWC). The $\mathrm{pH}$ and EC were measured by dipping glass electrode employing 1:1 soil /water (v/v) ratio. TC and TN were measured by combustion at $1800{ }^{\circ} \mathrm{C}$ using Vario Max CN Analyzer. Soil particle distribution was determined by hydrometer method [31] and textural class was assigned as per US textural classification. EP was determined using Mehlich-3 soil phosphorus test [32].

\section{Microbial DNA extraction, $16 S$ amplicon production and sequencing}

Microbial genomic DNA was extracted employing PowerSoil ${ }^{\circledR}$ DNA isolation kit (MoBio, Carslbad, CA) as per Earth Microbiome Project benchmarked protocols [33, 34]. Microbial community composition was assessed as per protocols and primers described [35] that target archaeal and bacterial hypervariable V4 region (515f/806r) of the 16S rRNA gene [36]. Amplicons of 16S rRNA gene were generated following amplification using HotStarTaq Plus Master Mix Kit (Qiagen) employing subsequent conditions: initial denaturation $\left(94{ }^{\circ} \mathrm{C}\right.$ for $\left.3 \mathrm{~min}\right)$ followed by 30 cycles, each set at $94{ }^{\circ} \mathrm{C}$ for 30 seconds, $53{ }^{\circ} \mathrm{C}$ for 40 seconds and $72{ }^{\circ} \mathrm{C}$ for $1 \mathrm{~min}$, with a final elongation step at $72{ }^{\circ} \mathrm{C}$ for 5 min. The PCR products were analyzed on $2 \%$ agarose gel. Multiple samples were pooled in equal proportions based on DNA concentration and molecular weight. The pooled samples were purified by calibrated Ampure XP beads and used to prepare DNA libraries following Illumina TruSeq DNA library preparation protocol. Sequencing was performed at the Molecular Research DNA laboratory (Shallowater, TX, USA) on an MiSeq (Illumina) platform in an overlapping $2 \times 300$ bp configuration with a minimum throughput of 20,000 reads for each sample.

\section{Processing of raw Illumina sequencing data}

151 Raw amplicon sequences of 16S rRNA were processed and analyzed following described protocols [37, 38]. In brief, 152 sequences were joined (overlapping pairs) and grouped by samples following the barcodes that were removed 153 afterwards. Then, sequences $<150$ bp or with ambiguous base calls were removed. Remaining sequences were filtered 
154 using the USEARCH clustering algorithm at $4 \%$ sequence divergence to remove chimeras and clusters consisting of only one sequence (i.e. singletons) [39]. The sequencing data for all the 18 samples was submitted in the Sequence Read Archive (SRA) of NCBI (National Center for Biotechnology Information) under the BioProject PRJNA627288 with accession numbers SAMN14661259 to SAMN14661276.

Sequence analysis, taxonomic identification, and diversity analysis

All the resulted sequences were analyzed with Quantitative Insights Into Microbial Ecology (QIIME 2 Core 2019) to obtain all $16 \mathrm{~S}$ rRNA reads from the amplicon with $97 \%$ similarity or 3\% divergence with the taxonomy of resulting Operational Taxonomic Units (OTUs) [40, 41]. The OTU selection process was performed with USearch (v6.1.544) using QIIME 2. The total number of OTUs analyzed were 14,087 comprising 1,509,246 reads at species level across 18 samples. Finally, all the OTSs were taxonomically categorized using BLASTn against RDPII and NCBI based database (www.ncbi.nlm.nih.gov, http://rdp.cme.msu.edu). The microbial diversity patterns were analyzed by calculating alpha OTU diversity using the alpha_rarefaction.py script in QIMME 2 [41]. The Shannon, Pielou E and Faith's Phylogenetic Diversity (PD) indices were calculated alongside observed OTUs ('richness') [42]. While for beta diversity pattern, Bray Curtis, Jaccard, Unweighted Unifrac and Weighted Unifrac distance matrices were calculated (data only shown) and reported [43].

\section{Functional diversity of microbial community}

170 Functional capabilities of microbial communities were predicted using sequencing data of 16S rRNA gene by 171 Phylogenetic Investigation of Communities by Reconstruction of Unobserved States (PICRUSt) [44]. The PICRUSt 172 software store the COG information and KEGG Ortholog (KO) information related to the greengene id and predict 173 metagenomes by standardizing OUT abundance. The KO and COG family information were obtained by greengene 174 id related to each OUT and the KO and COG abundance was obtained. The information of KO, EC and Pathway were 175 obtained from KEGG database thus functional categorization at three levels can be obtained according to OTU 176 abundance [45].

\section{Statistical Analysis}

178 The indexes of microbial alpha-diversity were estimated by mothur (version v1.30.1), including Pileou's E, Faith's 179 PD and Shannon [42]. Means and standard errors (SE) were calculated using Microsoft Excel 365. Multivariate analysis of variance (MANOVA) as Post-HOC test (Tukey's HSD) at the significance level of $\alpha=0.05$ ( $<<0.05$ ) was 
181 performed using SPPP (IBM SPSS Statistics for Windows, Version 26.0., Armonk, NY, USA). The HTS data was

182 computed by QIMME 2 [41] and principal component analysis (PCA) was performed in Canoco for Windows (version 4.5) and drawn in Cano Draw [46]. The hierarchical clustering was plotted using Euclidean distance method and Ward's minimum variance as clustering method and in BioVinci (Version: 1.1.5, r20181005). Details of evaluations are provided in results and discussion.

\section{Results}

\section{Physicochemical properties of soil}

Soil physicochemical properties showed variable effects of fertilization on bacterial and archaeal community composition. The $\mathrm{pH}$ varied between $7.68-8.28$ in four fertilizer regimes and significant variations were found for different combinations. The EC values were significantly increased in all treatments as compared to control and varied between 259-602 dS/cm being higher in UPK, UPRs, PKRs and UPKRs and lower in each control and U. Soil TC varied between $0.146-0.177 \%$ and found to increase in all treatments except KP and PKRs while TN varied between $1.34-1.64 \%$ and found to decrease only in U, P, KP, UK and PKRs. Soil OM and AK increased with the use of fertilizers and ranged between $0.72-2.79 \%$ and $6.4-13.2 \mathrm{mg} / \mathrm{kg}$, respectively. Variations in EP were insignificant in any treatment. Differences based on different treatments using physicochemical properties were outlined using PCA in figure 1 . The first two axes explained $33.5 \%$ and $25.5 \%$ of the overall variance. More variation is found in $\mathrm{C}_{0}$ and $\mathrm{C}_{\mathrm{f}}$ on the positive side of $\mathrm{PC} 1$ which is influenced by $\mathrm{pH}, \mathrm{GWC}$ and $\mathrm{EP}$ while TC, TN, OM, EC, and AK tend to influence on left side of biplot and influencing most of the samples. The biplot showed strong correlation between TC and TN; EP and GWC and EC, AK, and OM.

\section{Microbial community composition}

The sequencing results showed $3,237,072$ reads of $16 \mathrm{~S}$ rDNA which accounts for $92.51 \%$ of the total reads for bacteria. They were clustered into 13,918 OTUs from 18 soil samples and assigned 29 bacterial phyla and 902 genera. Overall, 10 major bacterial phyla contributed over $99 \%$ of bacterial community structure with Proteobacteria (3237\%), Actinobacteria (21-26\%) and Firmicutes (15-19\%) being the dominant ones. Other important bacterial phyla were Chloroflexi (9-15\%), Bacteroides (2-6\%), Acidobacteria (2-3\%) and Gemmatimonadetes (1-2\%). The relative abundance of dominant phyla and genera is shown (Figure 2). Chloroflexi, Bacteroides, Planctomycetes and Verrucomicrobia are found to increase in majority of treatment as compared to control. The dominant genera were 
bacillus followed by conexibacter, solirubrobacter, bellilinea and sphingomonas. Bellilinea, Pelobacter, Clostridium

and Dehalococcoides showed increasing trend, while converse was found for conexibacter, Solirubrobacter, Sphingomonas, Acidobacterium, Thermoleophilum and Frankia.

211 For archaea, 193,917 valid reads were obtained which contributed 5.54\% of overall diversity and clustered into 169

212 OTUs which are classified into 3 phyla, and 23 genera. Among the 3 archaeal phyla, Thaumarchaeota was the most 213 dominant followed by Euryarchaeota and Crenarchaeota and their relative abundance in all samples varied from 93-

$21497,1-6$ and $0.2-0.9 \%$ respectively (Figure 3 ). The dominant archaeal genera that gave $\sim 95 \%$ community coverage include Nitrososphaera (69-78\%), Candidatus (18-24\%), Methanobacterium (1-3\%) and Methanocella (1\%). Overall, an increasing trend was observed for Thaumarchaeota with their lowest abundance in $\mathrm{C}_{0}(93 \%)$ and highest in UK (98\%) and decreasing trend was found for Euryarchaeota with lowest in $\mathrm{K}(1.8 \%)$ and highest in $\mathrm{C}_{0}(6.2 \%)$. For archaeal phyla, Thaumarchaeota showed increasing, Euryarchaeota proved opposite and Crenarchaeota showed both trends. For Archaeal genera, Nitrososphaera and Methanosaeta showed increasing while the rest showed both trends.

The variation in archaeal community is also well pronounced in case of methanogens.

221 Variations in microbial community composition in different treatments are outlined by PCA (Figure 4). PC1 and PC2 accounted for $56.3 \%$ of the variance in microbial community which demonstrated separation and clustering in 223 microbial communities in soil with all treatments.

Observed OTUs, Evenness, Diversity and Bray-Curtis dissimilarity indices of microbial communities.

225 The observed OTUs and $\alpha$-diversity indexes like Pielou's E, Faith's PD and Shannon are shown (Table 2). Of all the 226 samples, the least OTUs were found in $\mathrm{C}_{0}$ and $\mathrm{C}_{\mathrm{f}}$ which represent lesser microbial activity without any amendment 227 and vice versa. Pielo's E and and Shannon's indexes were greater in all samples as compared to controls without plants 228 i-e $\mathrm{C}_{0}$ and $\mathrm{C}_{\mathrm{f}}$ while the Faith's $\mathrm{PD}$ was also lower in these controls as compared to all other samples.

230 The PICRUSt analysis demonstrated six primary functional levels, including, metabolism, genetic information 231 processing, environmental information processing, cellular processes, organ systems, and human diseases. The 232 functional profiles of metabolism at second and third level were predicted using PICRUSt and hierarchically clustered 233 as shown in figure 5. Regarding metabolism, the highest gene counts were found for amino acid and carbohydrate metabolism with lowest in sample $\mathrm{C}_{0}, \mathrm{C}_{\mathrm{f}}$ and $\mathrm{P}$ and highest in UKRs and KP which also indicate the overall trend of 
the community. The gene counts for energy metabolism, lipid metabolism, metabolism of cofactors and vitamin and xenobiotic degradation also showed increase as compared to control without plants i-e $\mathrm{C}_{0}$ and $\mathrm{C}_{\mathrm{f}}$. An approximate two-fold increase was observed for $\mathrm{C}_{\mathrm{neg}}, \mathrm{U}, \mathrm{K}, \mathrm{Rs}, \mathrm{KP}$, RsK, UPK, UPRs and UPKRs while three-fold increase was observed for UP and PKRs.

At third level, more pronounced differentiation was observed for carbon fixation pathways in prokaryotes, methane metabolism, nitrogen metabolism and oxidative phosphorylation in KP, UKRs, UPRs, UK and RsP than the rest of samples. The trend for variation against different samples was found to be synchronized with second level. Shift in the abundance and composition of functional metabolism can explain a functional category. The heat map demonstrated gene counts for methane metabolism being highest in KP (7.82\%), followed by UKRs (7.24\%), UPRs (6.78\%), $\mathrm{UK}(6.64 \%)$ and $\mathrm{U}(6.27 \%)$, while least in controls i-e $\mathrm{C}_{0}(2.76 \%)$ and $\mathrm{C}_{\mathrm{f}}(3.02 \%)$. At level 3, the microbial communities seem to respond considerably higher for oxidative phosphorylation (21.76\%), methane metabolism (18.26\%), and carbon fixation pathways in prokaryotes (17.79\%).

\section{Correlations}

Correlation analysis between physicochemical factors and relative abundance of dominant taxonomic bacterial and archaeal phyla are summarized in Table 3. It strongly indicated an association between $\mathrm{pH}, \mathrm{OM}$ and $\mathrm{AK}$ influencing positively on majority of bacterial phyla. Soil $\mathrm{pH}$ and EP negatively affect Proteobacteria and Bacteroidetes but positively with Actinobacteria and Firmicutes. pH seems to impact neutrally for archaea except Crenarchaeota. The concentration of soil organic matter is positively correlated with all bacterial phyla except Actinobacteria and negatively correlated with Euryarchaeota and Crenarchaeota. Soil EC and AK had a positive impact on Proteobacteria, Bacteroidetes, Gemmatimonodetes and Thaumarchaeota and negative impact on Actinobacteria, Chloroflexi, Euryarchaeota and Crenarchaeota. Soil TC and TN is positively correlated with Verrucomicrobia, Euryarchaeota and Crenarchaeota. The RDA analysis between soil physicochemical properties and microbial compositions explained $29.1 \%$ and $18.5 \%$ variance for RD1 and RD2 axes, respectively (Figure 6). Actinobacteria $(\mathrm{F}=2.55, \mathrm{P}=0.02)$ and Nitrospirae $(\mathrm{F}=1.71, \mathrm{P}=0.05)$ were correlated significantly with soil physicochemical properties.

\section{Discussion}


261 As far as organic and inorganic supplementation of paddy soil concerned, the current study characterized a comprehensive investigation of consequent microbial community variations in paddy soil in terms of structure and

263 function. It also focused the quantification, diversification, and metabolic functional prediction at different levels of 264 two key microbial groups i.e., bacteria and archaea. Thus, it gave us better insight on fertilizer usage with respect to methanogens in soil microbiome.

Soil physicochemical properties treated with various fertilizers has been reported to impact bacterial and archaeal community structure [47]. The $\mathrm{pH}$ of soil did not vary significantly in our study against different treatments. The flooded conditions in soil have been known to stabilize $\mathrm{pH}$ by inhibiting nitrification which is acid producing process [48]. Although $\mathrm{pH}$ is known to be a considerate factor in shaping microbial communities [49], some studies has reported otherwise in clay loam [50]. After subsequent inorganic and organic supplementation, significant increase in $\mathrm{EC}, \mathrm{AK}$ and $\mathrm{OM}$ was observed which were strongly correlated to each other and poorly to $\mathrm{pH}$ (Figure 1) as previously reported [3]. PCA biplot showed strong correlation between OM and AK; TC and TN; GWC, EP and pH [51] . OM and $\mathrm{AK}$ also showed negative correlation with $\mathrm{TC}$ and $\mathrm{TN}$ while weak correlation with GWC, EP and $\mathrm{pH}$. With respect to different treatments, strong association in microbial composition between KP, PKRs and UK is noted, while the rest of sample showed distinction of varying degree from each other. TC and TN have been showed to positively influence Rs, URs, RsP, UPRs and UPKRs. In particular, the control treatments $\mathrm{C}_{0}$ and $\mathrm{C}_{\mathrm{f}}$ were separated from $\mathrm{C}_{\text {neg }}$ as well as from other treated samples. No significant variation in TC, TN and EP was observed, which are usually known to increase with straw application and NPK fertilizations, respectively. The possible explanation could be increased CNP efficiency in flooded soil for plant uptake to satisfy their needs. Our results correspond to specific soil used in the study and considerable variation could have occurred due to soil texture, temperature, mineralogy, $\mathrm{pH}$, and OM.

282 The microbial community succession under the influence of NKP and rice straw are well documented in wetland ecology and rice fields [52]. TC and TN seems to impact negatively or neutrally for majority of bacterial phyla while for archaeal phyla they were positively correlated except thaumarchaeota. This exception can be supported by the fact that fungi are more dependent on $\mathrm{C}$ and $\mathrm{N}$ sources than bacteria and archaea [53]. Total bacterial and archaeal population increased for every test sample as compared to control, however that increase was not sharp in case of bacteria [54] and a moderate increase under flooded conditions has also been reported [55]. Phylum Proteobacteria 
copiotrophic lifestyle of paddy soil [57] and the prevalence of other dominant phyla i-e Actinobacteria, Firmicutes, Chloroflexi, Bacteroidetes, Acidobacteria etc is also well documented $[3,55,57,58]$ and is in accordance with our results [59]. Bacterial phyla, Chloroflexi, Bacteroidetes, Planctomycetes and Verrucomicrobia showed increased in population size as compared to control while Actinobacteria, Acidobacteria and Gemmatimonadetes showed negative trend $[10,60]$. Previous studies also report more response of bacterial diversity in the presence of inorganic fertilizer along with rice straw which satisfy our results for all cases except UPKRs [61-63]. One contrary finding in our current study was of Verrucomicrobia, which has been reported to decrease with rice straw incorporation and increase during chronic N incorporation [2, 60,64]. Additionally, RDA analysis showed Actinobacteria and Nitrospirae being correlated with soil physicochemical properties (Figure 6). It also showed time zero control $\left(\mathrm{C}_{0}\right)$ well separated from all treatments with maximum Actinobacteria population. Since microbial diversity in soil is always multifactorial dependent, competitive inhibition due to multiple fertilization may justify our results. One such example is of carrier ions (chloride ions in our case from $\mathrm{KCl}$ ). Chloride ions being a strong oxidant act as a potential biocide and have been studied to obstruct nitrification even at low concentration $[65,66]$. This study also suggest that Bacillus does not seem to be very responsive genera for almost each combination except UPRs and UPKRs which propose that rice straw in combination $\mathrm{U}$ and P may shift the functional dynamics of Bacillus. Additionally, rice straw incorporation has been reported extensively to stimulate bacterial communities in paddy soil and our results are in accordance with it $[2,67,68]$. Since multiple bacterial, fungal, and archaeal phyla with various functions were operating, it cannot be concluded which specific factor altered their shift in our study.

307 The soil archaeal community in rice fields are reported to be more stable unless influenced by temperature or presence 308 of organic matter such as rice straw [55, 69]. Our results suggested archaea (specifically methanogens) being more responsive as compared to bacteria concerning community structure and metabolic functioning due to $\mathrm{KCl}$

310 supplementation. The presence of methanogens such as Methanosarcinaceae, Methanosaetaceae, 311 Methanobacteriales, Methanomicrobiales, and Methanocellales in rice fields have been well supported [70-72]. There are controversies in literature suggesting $\mathrm{N}$-fertilization can stimulate $[73,74]$ or inhibit $[75,76]$ methanogenesis in

313 wetland ecosystems but our results showed mutual cases for the most abundant group i-e Methanobacteriam. Most of 314 the test samples showed increasing trend except $\mathrm{U}, \mathrm{K}$ and $\mathrm{UK}$ treatments and reduced methanogenesis due to urea 315 [77] and potassium is documented [78]. 
316 Computational methodology to predict functional activities of microbial communities at metabolism level was

317 employed using PICRUSt. The idea was to compare marker genes of HTS with that of KEGG and COG databases

318 [44]. The hierarchical clustering of level 2 KEGG ortholog function prediction at metabolism level showed that the

319 microbial community has responded more towards amino acid (20.66\%), carbohydrate (19.85\%), energy (10.76\%)

320 and lipid metabolism (7.23\%) and less towards glycan biosynthesis, synthesis of secondary metabolites, terpenoids

321 and biodegradation $(1.8-7 \%)$. Few studies has predicted the prevalence and abundance of carbon $(\mathrm{C})$, nitrogen $(\mathrm{N})$

322 and phosphorus (P) cycle related genes [79-82]. At energy metabolism level, methane metabolism, which is

323 confiscated by methanogenesis, was higher since the experimental soil was under flooded conditions. The process is

324 entirely restricted to methanogens which can be either hydrogenotrophic methanogens or acetoclastic methanogens.

325 Previous studies support acetoclastic pathway and the aceticlasic methanogens Methanosaeta [57] were also seemed

326 to increase in our test samples.

\section{Conclusions}

328 In the current study, we compared the effects of $\mathrm{N}, \mathrm{P}, \mathrm{K}$, and rice straw in pure and mixed form on overall microbial 329 community structure and diversity in a planted paddy soil microcosm. Different treatments influenced the 330 physicochemical parameters which were driving factors in microbial community structure. In pure form the highest 331 diversity in found against Rs and least for P as represented by OTUs, Faith's PD and Shannon indices. Also, PCA 332 showed more resemblance of $\mathrm{U}$ with $\mathrm{C}_{0}$ and $\mathrm{C}_{\mathrm{f}}$. In mixed treatments the highest diversity is found in soil supplemented 333 with KP and least in quadruple treatment i-e UPKRs. Overall, archaea were found more responsive against all 334 amendments than bacteria. Compared to each control and single fertilizers, double and triple combinations let to 335 greater diversity. The PICRUSt derived functional profile energy and methane metabolism also indicated KP as most responsive and $\mathrm{P}, \mathrm{C}_{0}$ and $\mathrm{C}_{\mathrm{f}}$ as least responsive. It also revealed that mixed fertilization can potentially increase the

337 methane metabolism amongst microbial community. Additionally, the current results imply that a caution must be 338 exercised in flooded agricultural systems regarding the use of $\mathrm{KCl}$ to regulate methane emission. The amendments 339 KP, UKRs, UPRs and UK were found most responsive in terms of methane metabolism and oxidative phosphorylation 340 while least response for nitrogen metabolism at the same time.

\section{Acknowledgements}


342 I am thankful for the technical assistance of Muhammad M. Hassan who carried out the sampling and laboratory

343 measurements, Nicola Lorenz who helped me in resources and technical assistance, Noshaba H Malik, who helped

344 me in formal analysis. I am also especially thankful to Richard Dick for resources and supervision and Naeem Ali for 345 supervision and project administration.

346 References

347 1. Welc M, Bünemann EK, Fließbach A, et al (2012) Soil bacterial and fungal communities along a soil $348 \quad$ chronosequence assessed by fatty acid profiling. Soil Biol Biochem 49:184-192.

349 https://doi.org/10.1016/j.soilbio.2012.01.032

350 2. Wu M, Qin H, Chen Z, et al (2011) Effect of long-term fertilization on bacterial composition in rice paddy $351 \quad$ soil. Biol Fertil Soils 47:397-405. https://doi.org/10.1007/s00374-010-0535-z

352 3. Wang J, Song Y, Ma T, et al (2017) Impacts of inorganic and organic fertilization treatments on bacterial 353 and fungal communities in a paddy soil. Appl Soil Ecol 112:42-50. https://doi.org/10.1016/j.apsoil.2017.01.005

355 4. Morris SJ, Blackwood CB (2015) The Ecology of the Soil Biota and their Function. In: Soil Microbiology, $356 \quad$ Ecology and Biochemistry. pp 273-309

357 5. Zhong WH, Cai ZC (2007) Long-term effects of inorganic fertilizers on microbial biomass and community 358 functional diversity in a paddy soil derived from quaternary red clay. Appl Soil Ecol 36:84-91. https://doi.org/10.1016/j.apsoil.2006.12.001

6. Ramirez KS, Craine JM, Fierer N (2012) Consistent effects of nitrogen amendments on soil microbial communities and processes across biomes. Glob Chang Biol 18:1918-1927. https://doi.org/10.1111/j.13652486.2012.02639.x

363

7. Eo J, Park KC (2016) Long-term effects of imbalanced fertilization on the composition and diversity of soil 364 bacterial community. Agric Ecosyst Environ 231:176-182. https://doi.org/10.1016/j.agee.2016.06.039

365 8. Su JQ, Ding LJ, Xue K, et al (2015) Long-term balanced fertilization increases the soil microbial functional diversity in a phosphorus-limited paddy soil. Mol Ecol 24:136-150. https://doi.org/10.1111/mec.13010 
367 9. Thielemann T, Lücke A, Schleser GH, Littke R (2000) Methane exchange between coal-bearing basins and the atmosphere: The Ruhr Basin and the Lower Rhine Embayment, Germany. Org Geochem 31:1387-1408. https://doi.org/10.1016/S0146-6380(00)00104-2

10. Li W, Liu M, Wu M, et al (2019) Bacterial community succession in paddy soil depending on rice fertilization. Appl Soil Ecol 144:92-97. https://doi.org/10.1016/j.apsoil.2019.07.014

372

11. Kikuchi H, Watanabe T, Jia Z, et al (2007) Molecular analyses reveal stability of bacterial communities in bulk soil of a Japanese paddy field: Estimation by denaturing gradient gel electrophoresis of 16S rRNA genes amplified from DNA accompanied with RNA. Soil Sci Plant Nutr 53:448-458. https://doi.org/10.1111/j.1747-0765.2007.00177.x

12. Kamaa M, Mburu H, Blanchart E, et al (2011) Effects of organic and inorganic fertilization on soil bacterial and fungal microbial diversity in the Kabete long-term trial, Kenya. Biol Fertil Soils 47:315-321. https://doi.org/10.1007/s00374-011-0539-3

13. Pazinato JM, Paulo EN, Mendes LW, et al (2010) Molecular characterization of the archaeal community in an Amazonian wetland soil and culture-dependent isolation of methanogenic archaea. Diversity 2:10261047. https://doi.org/10.3390/d2071026

14. Le Mer J, Roger P (2001) Production, oxidation, emission and consumption of methane by soils: A review. Eur. J. Soil Biol. 37:25-50

15. Griggs DJ, Noguer M (2002) Climate change 2001: The scientific basis. Contribution of working group I to the third assessment report of the intergovernmental panel on climate change. Weather 57:267-269. https://doi.org/10.1256/004316502320517344

16. Zhang G, Zhang X, Ma J, et al (2011) Effect of drainage in the fallow season on reduction of CH4 production and emission from permanently flooded rice fields. Nutr Cycl Agroecosystems 89:81-91. https://doi.org/10.1007/s10705-010-9378-0 community structure in tropical irrigated Indian paddy soils. Biol Fertil Soils 50:369-379. 
18. Gulledge J, Doyle AP, Schimel JP (1997) Different NH4/+-inhibition patterns of soil CH4 consumption: A result of distinct CH4-oxidizer populations across sites. Soil Biol Biochem 29:13-21. https://doi.org/10.1016/S0038-0717(96)00265-9

19. Khush GS (2005) What it will take to Feed 5.0 Billion Rice consumers in 2030. Plant Mol. Biol. 59:1-6

20. Dubey SK (2005) Microbial ecology of methane emission in rice agroecosystem: A review. Appl. Ecol. Environ. Res. 3:1-27

21. Singh JS, Strong PJ (2016) Biologically derived fertilizer: A multifaceted bio-tool in methane mitigation. Ecotoxicol. Environ. Saf. 124:267-276

22. Niswati A, Murase J, Kimura M (2005) Effect of application of rice straw and compost on the bacterial communities associated with Moina sp. in the floodwater of a paddy soil microcosm: Estimation based on DGGE pattern and sequence analyses. Soil Sci Plant Nutr 51:565-571. https://doi.org/10.1111/j.17470765.2005.tb00065.x

23. Pan F, Li Y, Chapman SJ, Yao H (2016) Effect of rice straw application on microbial community and activity in paddy soil under different water status. Environ Sci Pollut Res 23:5941-5948. https://doi.org/10.1007/s11356-015-5832-5

24. Kuppusamy S, Daquiado AR, Kim SY, et al (2018) Agriculturally relevant microbial community structure in long-term fertilized paddy soils as revealed by phospholipid fatty acid (PLFA) and pyrosequencing analyses. Arch Agron Soil Sci 64:1379-1393. https://doi.org/10.1080/03650340.2018.1436761

411 25. Wachinger G, Fiedler S, Zepp K, et al (2000) Variability of soil methane production on the micro-scale: spatial association with hot spots of organic material and Archaeal populations. Soil Biol Biochem 32:11211130. https://doi.org/10.1016/S0038-0717(00)00024-9

414 26. Mahmood K, Ul-Haq Z, Faizi F, et al (2019) Monitoring open dumping of municipal waste in Gujranwala, 415 Pakistan using a combination of satellite based bio-thermal indicators and GIS analysis. Ecol Indic 107:. https://doi.org/10.1016/j.ecolind.2019.105613 
417 27. Zheng Y, Zhang LM, He JZ (2013) Immediate effects of nitrogen, phosphorus, and potassium amendments on the methanotrophic activity and abundance in a Chinese paddy soil under short-term incubation experiment. J Soils Sediments 13:189-196. https://doi.org/10.1007/s11368-012-0601-2

420

421

422

423

28. Shrestha M, Shrestha PM, Frenzel P, Conrad R (2010) Effect of nitrogen fertilization on methane oxidation, abundance, community structure, and gene expression of methanotrophs in the rice rhizosphere. ISME J 4:1545-1556. https://doi.org/10.1038/ismej.2010.89

29. Baldoncini M, Albéri M, Bottardi C, et al (2019) Biomass water content effect on soil moisture assessment via proximal gamma-ray spectroscopy. Geoderma 335:69-77. https://doi.org/10.1016/j.geoderma.2018.08.012

30. de Paul Obade V (2019) Integrating management information with soil quality dynamics to monitor agricultural productivity. Sci Total Environ 651:2036-2043. https://doi.org/10.1016/j.scitotenv.2018.10.106

31. Bouyoucos GJ (1962) Hydrometer Method Improved for Making Particle Size Analyses of Soils 1 . Agron J 54:464-465. https://doi.org/10.2134/agronj1962.00021962005400050028x

32. Mehlich A (1984) Mehlich 3 Soil Test Extractant: A Modification of Mehlich 2 Extractant. Commun Soil Sci Plant Anal 15:1409-1416. https://doi.org/10.1080/00103628409367568

33. Marotz C, Amir A, Humphrey G, et al (2017) DNA extraction for streamlined metagenomics of diverse environmental samples. Biotechniques 62:290-293. https://doi.org/10.2144/000114559

34. Thompson LR, Sanders JG, McDonald D, et al (2017) A communal catalogue reveals Earth's multiscale microbial diversity. Nature 551:457-463. https://doi.org/10.1038/nature24621

35. McHugh TA, Schwartz E (2016) A watering manipulation in a semiarid grassland induced changes in fungal but not bacterial community composition. Pedobiologia (Jena) 59:121-127. https://doi.org/10.1016/j.pedobi.2016.04.003

36. Caporaso JG, Lauber CL, Walters WA, et al (2011) Global patterns of 16S rRNA diversity at a depth of millions of sequences per sample. Proc Natl Acad Sci U S A 108:4516-4522. https://doi.org/10.1073/pnas.1000080107 
442 37. Dowd SE, Callaway TR, Wolcott RD, et al (2008) Evaluation of the bacterial diversity in the feces of cattle using 16S rDNA bacterial tag-encoded FLX amplicon pyrosequencing (bTEFAP). BMC Microbiol 8:. https://doi.org/10.1186/1471-2180-8-125

445

446

38. Handl S, Dowd SE, Garcia-Mazcorro JF, et al (2011) Massive parallel 16S rRNA gene pyrosequencing reveals highly diverse fecal bacterial and fungal communities in healthy dogs and cats. FEMS Microbiol Ecol 76:301-310. https://doi.org/10.1111/j.1574-6941.2011.01058.x

39. Edgar RC, Haas BJ, Clemente JC, et al (2011) UCHIME improves sensitivity and speed of chimera detection. Bioinformatics 27:2194-2200. https://doi.org/10.1093/bioinformatics/btr381

40. Jiang B, Adebayo A, Jia J, et al (2019) Impacts of heavy metals and soil properties at a Nigerian e-waste site on soil microbial community. J Hazard Mater 362:187-195. https://doi.org/10.1016/j.jhazmat.2018.08.060

41. Bolyen E, Rideout JR, Dillon MR, et al (2019) Reproducible, interactive, scalable and extensible microbiome data science using QIIME 2. Nat. Biotechnol. 37:852-857

42. Schloss PD, Westcott SL, Ryabin T, et al (2009) Introducing mothur: Open-source, platform-independent, community-supported software for describing and comparing microbial communities. Appl Environ Microbiol 75:7537-7541. https://doi.org/10.1128/AEM.01541-09

43. Lozupone C, Knight R (2005) UniFrac: A new phylogenetic method for comparing microbial communities. Appl Environ Microbiol 71:8228-8235. https://doi.org/10.1128/AEM.71.12.8228-8235.2005

44. Langille MGI, Zaneveld J, Caporaso JG, et al (2013) Predictive functional profiling of microbial communities using 16S rRNA marker gene sequences. Nat Biotechnol 31:814-821. https://doi.org/10.1038/nbt.2676

45. Malik AA, Puissant J, Buckeridge KM, et al (2018) Land use driven change in soil pH affects microbial carbon cycling processes. Nat Commun 9:. https://doi.org/10.1038/s41467-018-05980-1

46. ter Braak CJF, Šmilauer P (2002) CANOCO Reference Manual and CanoDraw for Windows User's Guide: Software for Canonical Community Ordination (Version 4.5). Sect Permut Methods Microcomput Power, Ithaca, New York 10. https://doi.org/citeulike-article-id:7231853 
467 47. Hoshino YT, Morimoto S, Hayatsu M, et al (2011) Effect of soil type and fertilizer management on archaeal community in upland field soils. Microbes Environ 26:307-316. https://doi.org/10.1264/jsme2.ME11131

469

470

471

472

473

474

475

476

477

478

479

480

481

482

48. Mi W, Sun Y, Xia S, et al (2018) Effect of inorganic fertilizers with organic amendments on soil chemical properties and rice yield in a low-productivity paddy soil. Geoderma 320:23-29.

https://doi.org/10.1016/j.geoderma.2018.01.016

49. Shen C, Xiong J, Zhang H, et al (2013) Soil pH drives the spatial distribution of bacterial communities along elevation on Changbai Mountain. Soil Biol Biochem 57:204-211.

https://doi.org/10.1016/j.soilbio.2012.07.013

50. Zhang Q, Zhou W, Liang G, et al (2015) Effects of different organic manures on the biochemical and microbial characteristics of albic paddy soil in a short-term experiment. PLoS One 10: https://doi.org/10.1371/journal.pone.0124096

51. Li Y, Wang S, Lu M, et al (2019) Rhizosphere interactions between earthworms and arbuscular mycorrhizal fungi increase nutrient availability and plant growth in the desertification soils. Soil Tillage Res 186:146151. https://doi.org/10.1016/j.still.2018.10.016

52. Iocoli GA, Zabaloy MC, Pasdevicelli G, Gómez MA (2019) Use of biogas digestates obtained by anaerobic digestion and co-digestion as fertilizers: Characterization, soil biological activity and growth dynamic of Lactuca sativa L. Sci Total Environ 647:11-19. https://doi.org/10.1016/j.scitotenv.2018.07.444

53. Schmidt SK, Nemergut DR, Darcy JL, Lynch R (2014) Do bacterial and fungal communities assemble differently during primary succession? Mol. Ecol. 23:254-258

54. Lee HJ, Kim SY, Kim PJ, et al (2014) Methane emission and dynamics of methanotrophic and methanogenic communities in a flooded rice field ecosystem. FEMS Microbiol Ecol 88:195-212. https://doi.org/10.1111/1574-6941.12282

55. Breidenbach B, Conrad R (2014) Seasonal dynamics of bacterial and archaeal methanogenic communities in flooded rice fields and effect of drainage. Front Microbiol 5:. https://doi.org/10.3389/fmicb.2014.00752

56. Zhan Y, Liu W, Bao Y, et al (2018) Fertilization shapes a well-organized community of bacterial 
decomposers for accelerated paddy straw degradation. Sci Rep 8:. https://doi.org/10.1038/s41598-018$26375-8$

494

57. Wang H, Zeng Y, Guo C, et al (2018) Bacterial, archaeal, and fungal community responses to acid mine drainage-laden pollution in a rice paddy soil ecosystem. Sci Total Environ 616-617:107-116. https://doi.org/10.1016/j.scitotenv.2017.10.224

58. Itoh H, Ishii S, Shiratori Y, et al (2013) Seasonal transition of active bacterial and archaeal communities in relation to water management in paddy soils. Microbes Environ 28:370-380. https://doi.org/10.1264/jsme2.ME13030

59. Chen C, Zhang J, Lu M, et al (2016) Microbial communities of an arable soil treated for 8 years with organic and inorganic fertilizers. Biol Fertil Soils 52:455-467. https://doi.org/10.1007/s00374-016-1089-5

60. Cederlund H, Wessén E, Enwall K, et al (2014) Soil carbon quality and nitrogen fertilization structure bacterial communities with predictable responses of major bacterial phyla. Appl Soil Ecol 84:62-68. https://doi.org/10.1016/j.apsoil.2014.06.003

61. Chidthaisong A, Inubushi K, Muramatsu Y, Watanabe I (1996) Production Potential and Emission of Methane in Flooded Rice soil Microcosms after Continuous Application of Straws. Microbes Environ 11:73-78. https://doi.org/10.1264/jsme2.11.73

62. Rath AK, Mohanty SR, Mishra S, et al (1999) Methane production in unamended and rice-straw-amended soil at different moisture levels. Biol Fertil Soils 28:145-149. https://doi.org/10.1007/s003740050476

63. Conrad R (2002) Control of microbial methane production in wetland rice fields. In: Nutrient Cycling in Agroecosystems. pp 59-69

64. Nemergut DR, Townsend AR, Sattin SR, et al (2008) The effects of chronic nitrogen fertilization on alpine tundra soil microbial communities: Implications for carbon and nitrogen cycling. Environ Microbiol 10:3093-3105. https://doi.org/10.1111/j.1462-2920.2008.01735.x

65. Chowdhury N, Marschner P, Burns R (2011) Response of microbial activity and community structure to decreasing soil osmotic and matric potential. Plant Soil 344:241-254. https://doi.org/10.1007/s11104-011- 
66. Vieira Megda MX, Mariano E, Leite JM, et al (2014) Chloride ion as nitrification inhibitor and its biocidal potential in soils. Soil Biol Biochem 72:84-87. https://doi.org/10.1016/j.soilbio.2014.01.030

520

67. Gong W, Yan X, Wang J, et al (2009) Long-term manure and fertilizer effects on soil organic matter fractions and microbes under a wheat-maize cropping system in northern China. Geoderma 149:318-324. https://doi.org/10.1016/j.geoderma.2008.12.010

68. Liu M, Hu F, Chen X, et al (2009) Organic amendments with reduced chemical fertilizer promote soil microbial development and nutrient availability in a subtropical paddy field: The influence of quantity, type and application time of organic amendments. Appl Soil Ecol 42:166-175.

https://doi.org/10.1016/j.apsoil.2009.03.006

69. Peng J, Lü Z, Rui J, Lu Y (2008) Dynamics of the methanogenic archaeal community during plant residue decomposition in an anoxic rice field soil. Appl Environ Microbiol 74:2894-2901. https://doi.org/10.1128/AEM.00070-08

70. Watanabe T, Kimura M, Asakawa S (2006) Community structure of methanogenic archaea in paddy field soil under double cropping (rice-wheat). Soil Biol Biochem 38:1264-1274. https://doi.org/10.1016/j.soilbio.2005.09.020

71. Wang G, Watanabe T, Jin J, et al (2010) Methanogenic archaeal communities in paddy field soils in northeast China as evaluated by PCR-DGGE, sequencing and real-time PCR analyses. Soil Sci Plant Nutr 56:831-838. https://doi.org/10.1111/j.1747-0765.2010.00521.x

72. Borrel G, Jézéquel D, Biderre-Petit C, et al (2011) Production and consumption of methane in freshwater lake ecosystems. Res Microbiol 162:832-847. https://doi.org/10.1016/j.resmic.2011.06.004

73. Banik A, Sen M, Sen SP (1996) Effects of inorganic fertilizers and micronutrients on methane production from wetland rice (Oryza sativa L.). Biol Fertil Soils 21:319-322. https://doi.org/10.1007/BF00334910

74. Shang Q, Yang X, Gao C, et al (2011) Net annual global warming potential and greenhouse gas intensity in Chinese double rice-cropping systems: A 3-year field measurement in long-term fertilizer experiments. Glob 
543

75. Xie B, Zheng X, Zhou Z, et al (2010) Effects of nitrogen fertilizer on CH 4 emission from rice fields: Multisite field observations. Plant Soil 326:393-401. https://doi.org/10.1007/s11104-009-0020-3

76. Dong H, Yao Z, Zheng X, et al (2011) Effect of ammonium-based, non-sulfate fertilizers on CH4 emissions from a paddy field with a typical Chinese water management regime. Atmos Environ 45:1095-1101. https://doi.org/10.1016/j.atmosenv.2010.11.039

77. Zou J, Huang Y, Jiang J, et al (2005) A 3-year field measurement of methane and nitrous oxide emissions from rice paddies in China: Effects of water regime, crop residue, and fertilizer application. Global Biogeochem Cycles 19:1-9. https://doi.org/10.1029/2004GB002401

78. Sheng R, Chen A, Zhang M, et al (2016) Transcriptional activities of methanogens and methanotrophs vary with methane emission flux in rice soils under chronic nutrient constraints of phosphorus and potassium. Biogeosciences 13:6507-6518. https://doi.org/10.5194/bg-13-6507-2016

79. Hartman WH, Ye R, Horwath WR, Tringe SG (2017) A genomic perspective on stoichiometric regulation of soil carbon cycling. ISME J 11:2652-2665. https://doi.org/10.1038/ismej.2017.115

80. Kang S, LeBrun ES (2018) A comparison of computationally predicted functional metagenomes and microarray analysis for microbial P cycle genes in a unique basalt-soil forest [version 1; referees: 2 approved]. F1000Research 7:. https://doi.org/10.12688/f1000research.13841.1

81. Hu Y, Zhang Z, Huang L, et al (2019) Shifts in soil microbial community functional gene structure across a 61-year desert revegetation chronosequence. Geoderma 347:126-134. https://doi.org/10.1016/j.geoderma.2019.03.046

82. Chen Y, Tian W, Shao Y, et al (2020) Miscanthus cultivation shapes rhizosphere microbial community structure and function as assessed by Illumina MiSeq sequencing combined with PICRUSt and FUNGUIld analyses. Arch Microbiol 202:1157-1171. https://doi.org/10.1007/s00203-020-01830-1 
567 Graphical Abstract

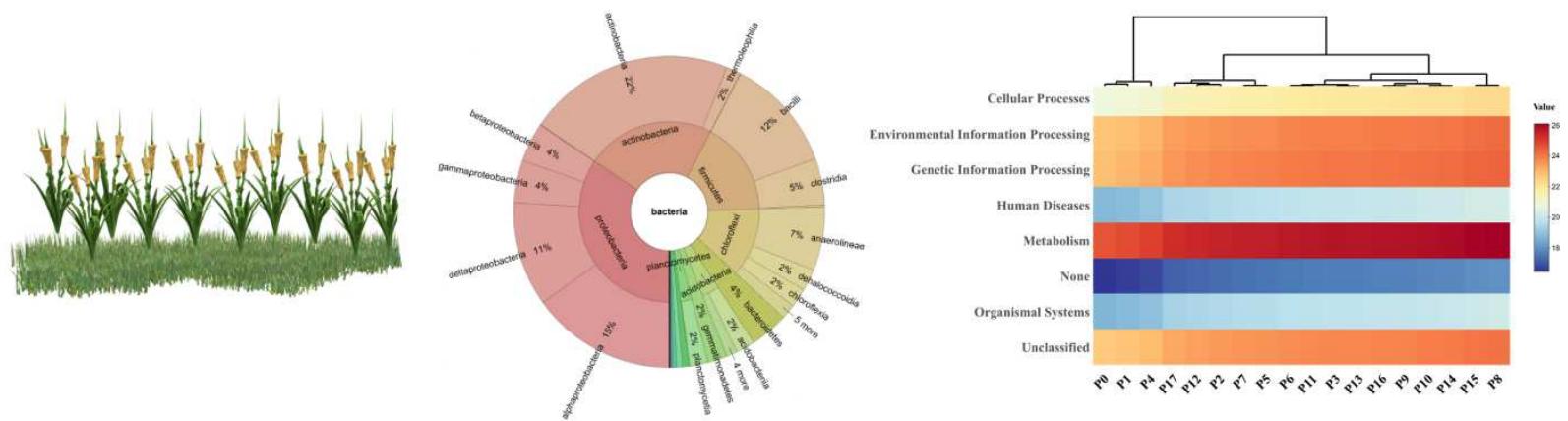

$\sum$ NPK fertilization $>$ Microbial community $>$ Predicted functional profile


Tables

Table 1: Description and supplementation of each microcosm setup with symbols used in this context.

\begin{tabular}{|c|c|c|}
\hline Pot ID & Treatment & Symbol \\
\hline 0 & Non-supplemented, Non-flooded & $\mathrm{C}_{0}$ \\
\hline 1 & Non-supplemented, Flooded & $\mathrm{C}_{\mathrm{f}}$ \\
\hline 2 & Non-supplemented, Flooded, Planted & $\mathrm{C}_{\text {neg }}$ \\
\hline 3 & $\mathrm{CO}\left(\mathrm{NH}_{2}\right)_{2}$, Planted & $\mathrm{U}$ \\
\hline 4 & $\mathrm{KH}_{2} \mathrm{PO}_{4}$, Planted & $\mathrm{P}$ \\
\hline 5 & $\mathrm{KCl}$, Planted & $\mathrm{K}$ \\
\hline 6 & Rice Straw, Planted & Rs \\
\hline 7 & $\mathrm{CO}\left(\mathrm{NH}_{2}\right)_{2}+\mathrm{KH}_{2} \mathrm{PO}_{4}$, Planted & UP \\
\hline 8 & $\mathrm{KCl}+\mathrm{KH}_{2} \mathrm{PO}_{4}$, Planted & KP \\
\hline 9 & Rice Straw $+\mathrm{KH}_{2} \mathrm{PO}_{4}$, Planted & RsP \\
\hline 10 & $\mathrm{CO}\left(\mathrm{NH}_{2}\right)_{2}+\mathrm{KCl}$, Planted & UK \\
\hline 11 & Rice Straw $+\mathrm{KCl}$, Planted & RsK \\
\hline 12 & $\mathrm{CO}\left(\mathrm{NH}_{2}\right)_{2}+$ Rice Straw, Planted & URs \\
\hline 13 & $\mathrm{CO}\left(\mathrm{NH}_{2}\right)_{2}+\mathrm{KH}_{2} \mathrm{PO}_{4}+\mathrm{KCl}$, Planted & UPK \\
\hline 14 & $\mathrm{CO}\left(\mathrm{NH}_{2}\right)_{2}+\mathrm{KH}_{2} \mathrm{PO}_{4}+$ Rice Straw, Planted & UPRs \\
\hline 15 & $\mathrm{CO}\left(\mathrm{NH}_{2}\right)_{2}+\mathrm{KCl}+$ Rice Straw, Planted & UKRs \\
\hline 16 & $\mathrm{KH}_{2} \mathrm{PO}_{4}+\mathrm{KCl}+$ Rice Straw, Planted & PKR \\
\hline 17 & $\mathrm{CO}\left(\mathrm{NH}_{2}\right)_{2}+\mathrm{KH}_{2} \mathrm{PO}_{4}+\mathrm{KCl}+$ Rice Straw, Planted & UPKRs \\
\hline
\end{tabular}

571

572

573

574

575

576

577

578

579 
581 Table 2: Observed OTUs and Alpha diversity indices for all treatments.

\begin{tabular}{|c|c|c|c|c|c|}
\hline Treatment & Observed OTUs & Pielou's E & Faith's PD & \multicolumn{2}{|c|}{ Shannon's Int8ex } \\
\hline$C_{0}$ & 1119 & 0.92 & 85.31 & 9.35 & \multirow{2}{*}{583} \\
\hline$C_{f}$ & 1306 & 0.92 & 99.69 & 9.55 & \\
\hline$C_{n e g}$ & 1852 & 0.92 & 128.15 & 9.96 & \multirow{2}{*}{584} \\
\hline $\boldsymbol{U}$ & 1981 & 0.92 & 132.56 & 10.02 & \\
\hline$P$ & 1391 & 0.92 & 109.00 & 9.56 & \multirow[t]{2}{*}{585} \\
\hline$K$ & 1733 & 0.90 & 117.06 & 9.74 & \\
\hline$R s$ & 2043 & 0.91 & 134.86 & 10.01 & \multirow[t]{2}{*}{586} \\
\hline$U P$ & 1844 & 0.91 & 129.45 & 9.91 & \\
\hline $\boldsymbol{K P}$ & 2421 & 0.91 & 155.74 & 10.25 & \multirow{2}{*}{587} \\
\hline$R s P$ & 2124 & 0.92 & 137.31 & 10.15 & \\
\hline$U K$ & 2102 & 0.91 & 133.98 & 10.08 & \multirow{2}{*}{588} \\
\hline$R s K$ & 2067 & 0.91 & 138.41 & 10.06 & \\
\hline URs & 1782 & 0.92 & 123.34 & 9.90 & \multirow{2}{*}{589} \\
\hline$U P K$ & 1982 & 0.91 & 129.11 & 9.99 & \\
\hline UPRs & 2260 & 0.92 & 142.80 & 10.21 & \multirow[b]{2}{*}{590} \\
\hline UKRs & 2256 & 0.91 & 141.06 & 10.14 & \\
\hline PKRs & 2125 & 0.92 & 137.16 & 10.14 & \multirow[b]{2}{*}{591} \\
\hline UPKRs & 1630 & 0.91 & 119.06 & 9.72 & \\
\hline
\end{tabular}

592

593

594

595

596

597

598

599

600 
601 Table 3: Correlation between physicochemical variables with bacterial and archaeal phyla $(*$ indicates archaeal 602 phyla)

\begin{tabular}{|c|c|c|c|c|c|c|c|}
\hline & $p H$ & $E C$ & Total C & Total N & $O M$ & $A K$ & $E P$ \\
\hline Proteobacteria & -0.30 & 0.23 & 0.13 & -0.01 & 0.23 & 0.24 & -0.28 \\
\hline Actinobacteria & 0.11 & -0.24 & 0.01 & -0.17 & -0.62 & -0.56 & 0.48 \\
\hline Firmicutes & 0.44 & -0.07 & -0.16 & -0.14 & 0.09 & -0.04 & 0.09 \\
\hline Chloroflexi & -0.04 & -0.14 & 0.01 & 0.22 & 0.09 & -0.08 & -0.10 \\
\hline Bacteroidetes & -0.35 & 0.27 & 0.09 & 0.10 & 0.30 & 0.40 & -0.13 \\
\hline Acidobacteria & 0.48 & -0.19 & -0.26 & -0.33 & -0.13 & 0.11 & -0.32 \\
\hline Planctomycetes & 0.18 & -0.01 & -0.20 & -0.08 & 0.21 & 0.04 & 0.00 \\
\hline Gemmatimonadetes & 0.13 & 0.28 & -0.17 & -0.22 & 0.34 & 0.56 & -0.09 \\
\hline Verrucomicrobia & -0.27 & 0.25 & 0.42 & 0.53 & 0.34 & 0.15 & 0.26 \\
\hline Nitrospirae & 0.57 & -0.17 & -0.37 & -0.30 & -0.10 & -0.04 & -0.19 \\
\hline Thaumarchaeota* & -0.06 & 0.24 & -0.28 & -0.20 & 0.31 & 0.44 & -0.08 \\
\hline Euryarchaeota* & 0.02 & -0.21 & 0.28 & 0.18 & -0.30 & -0.44 & 0.12 \\
\hline Crenarchaeota* & 0.32 & -0.40 & 0.14 & 0.33 & -0.25 & -0.25 & -0.21 \\
\hline
\end{tabular}

603

604

605

606

607

608

609

610

611

612

613

614 


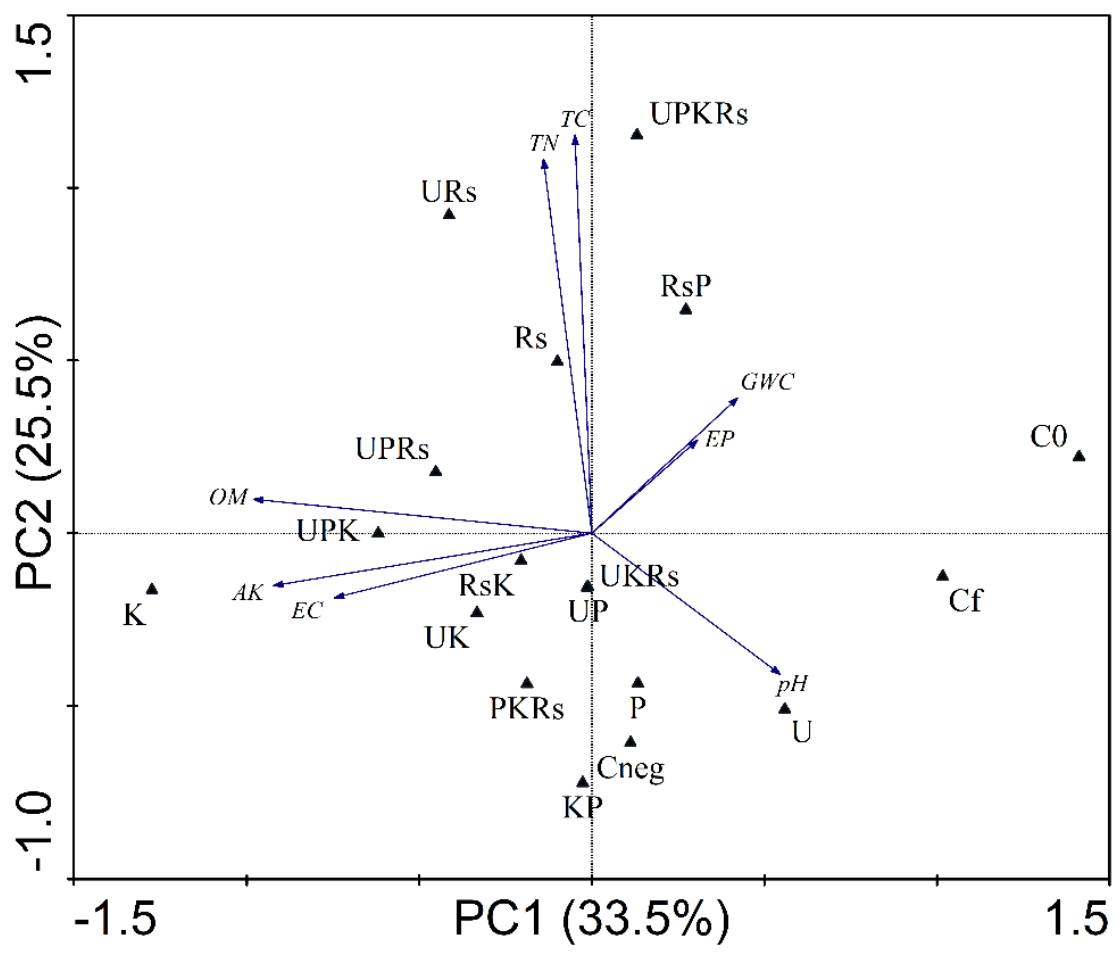

617

618 Fig 1: Principal component analysis (PCA) showing correlation biplot between explanatory soil variables (black 619 triangles) and loadings (blue lines). The symbols denote samples and are explained in Table 1. 


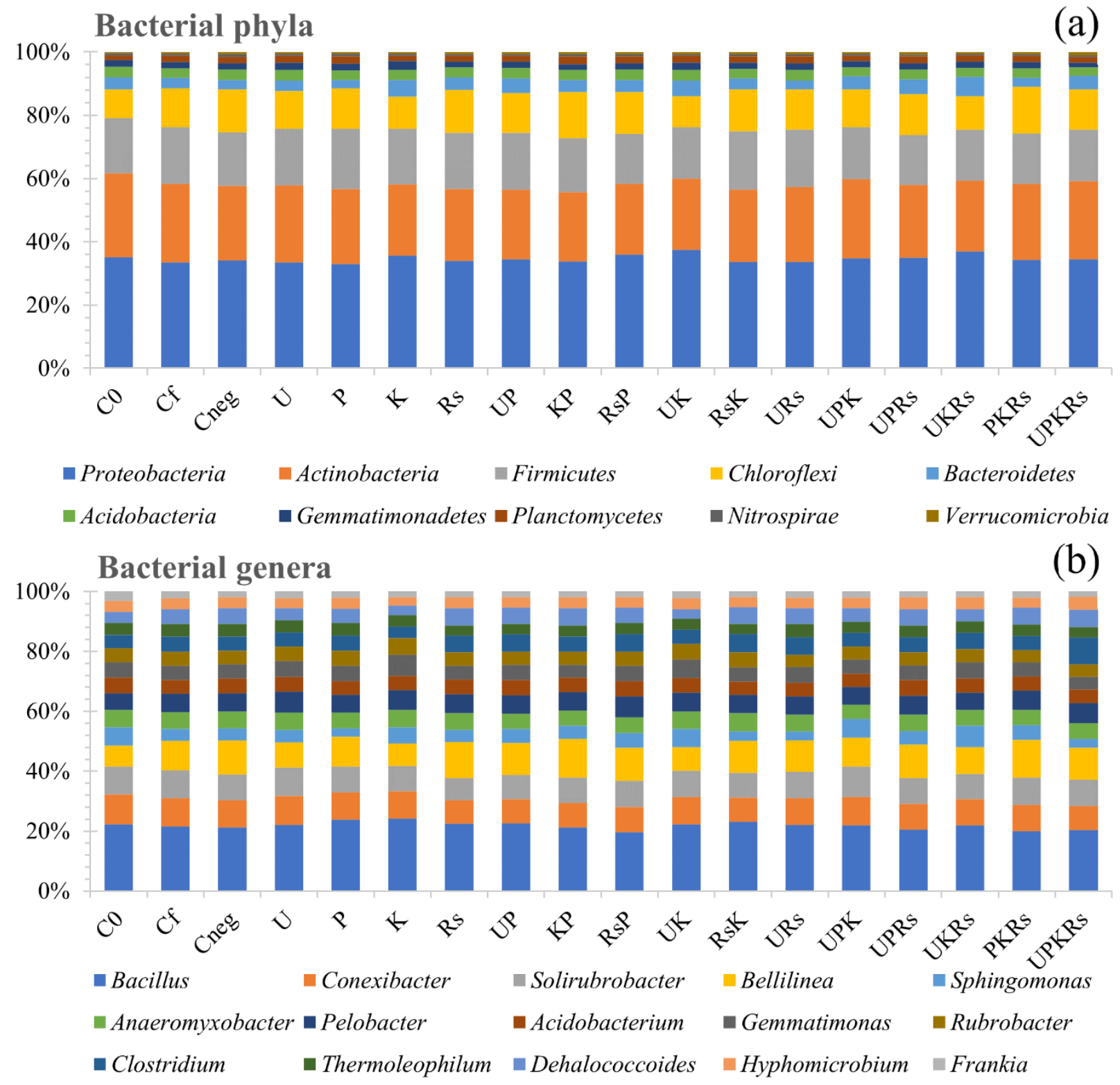




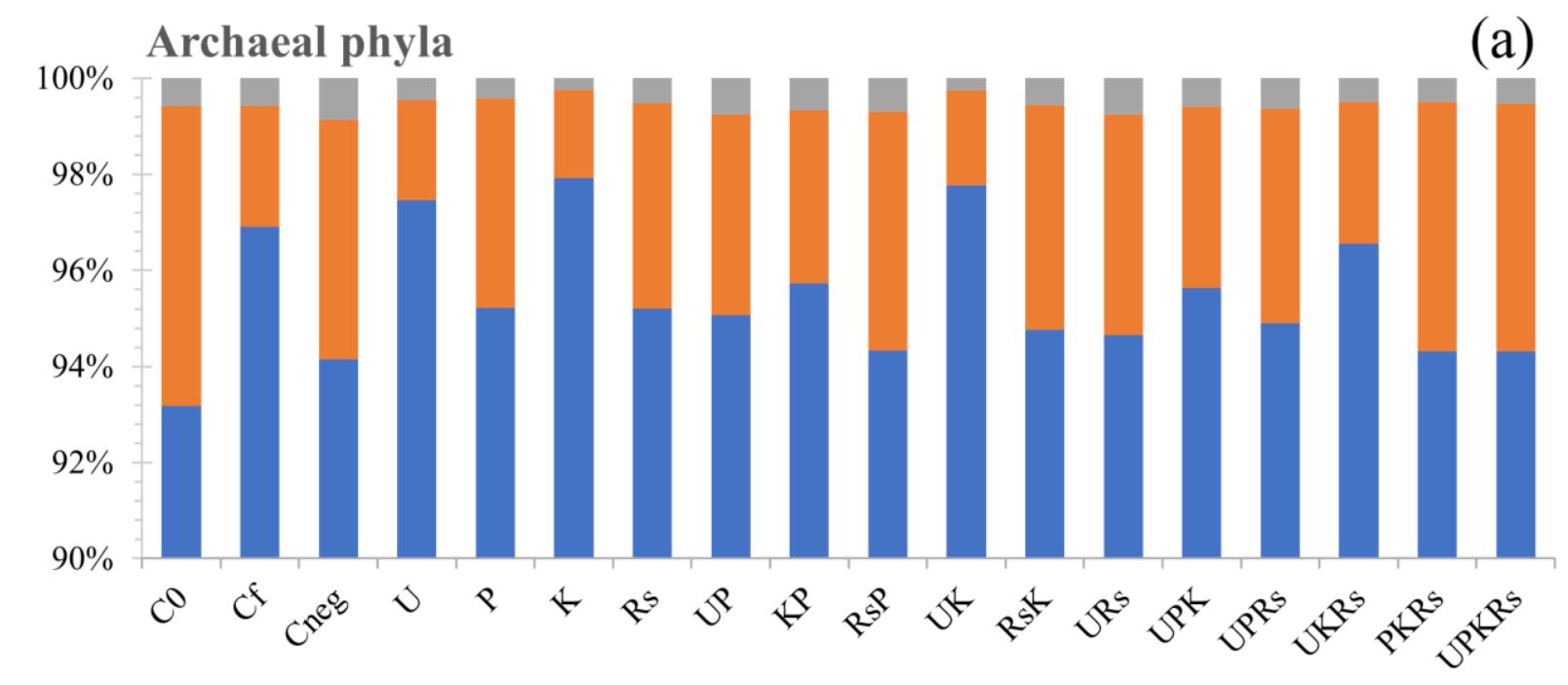

- Thaumarchaeota Euryarchaeota $\square$ Crenarchaeota

Archaeal genera

(b)

625

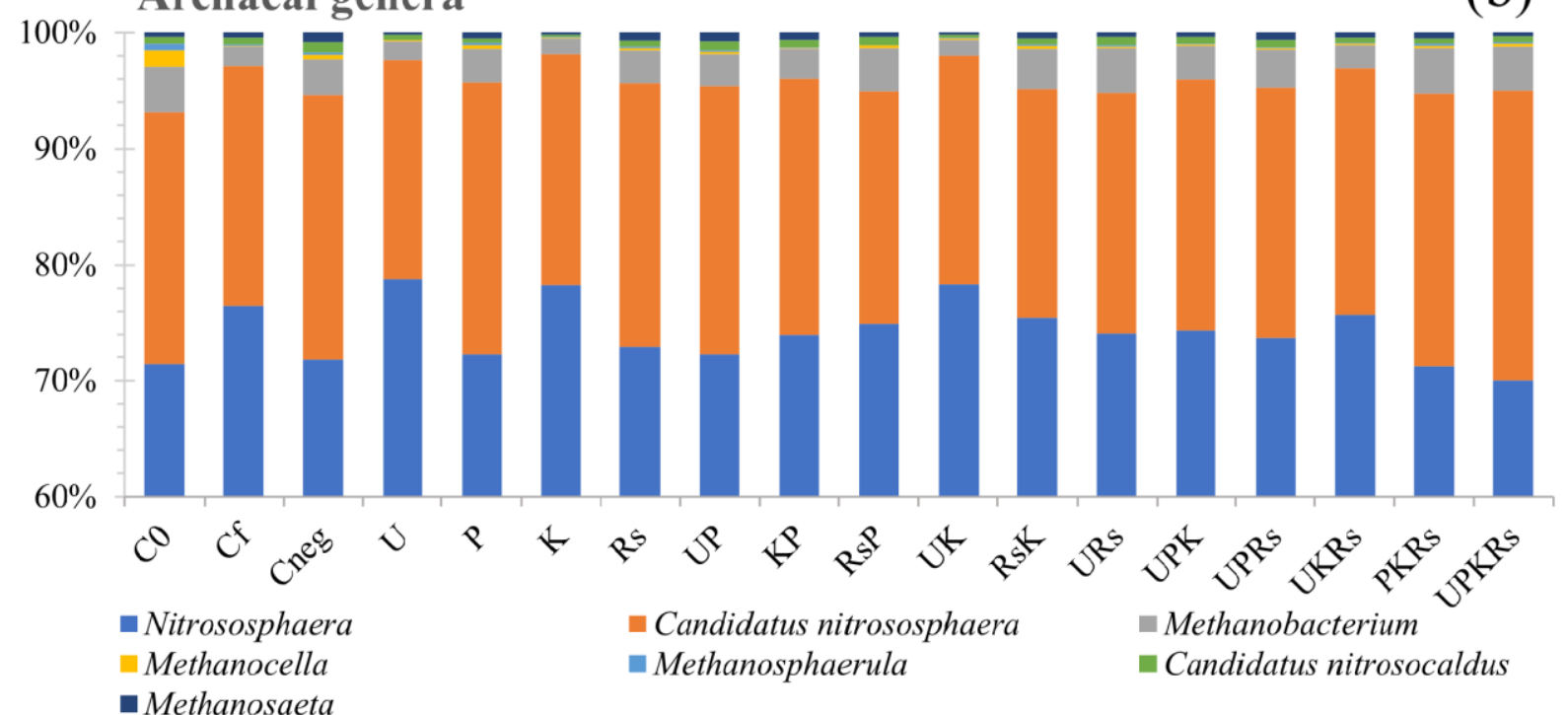

626 Fig 3: Relative abundance of archaeal phyla and genera in all samples. 


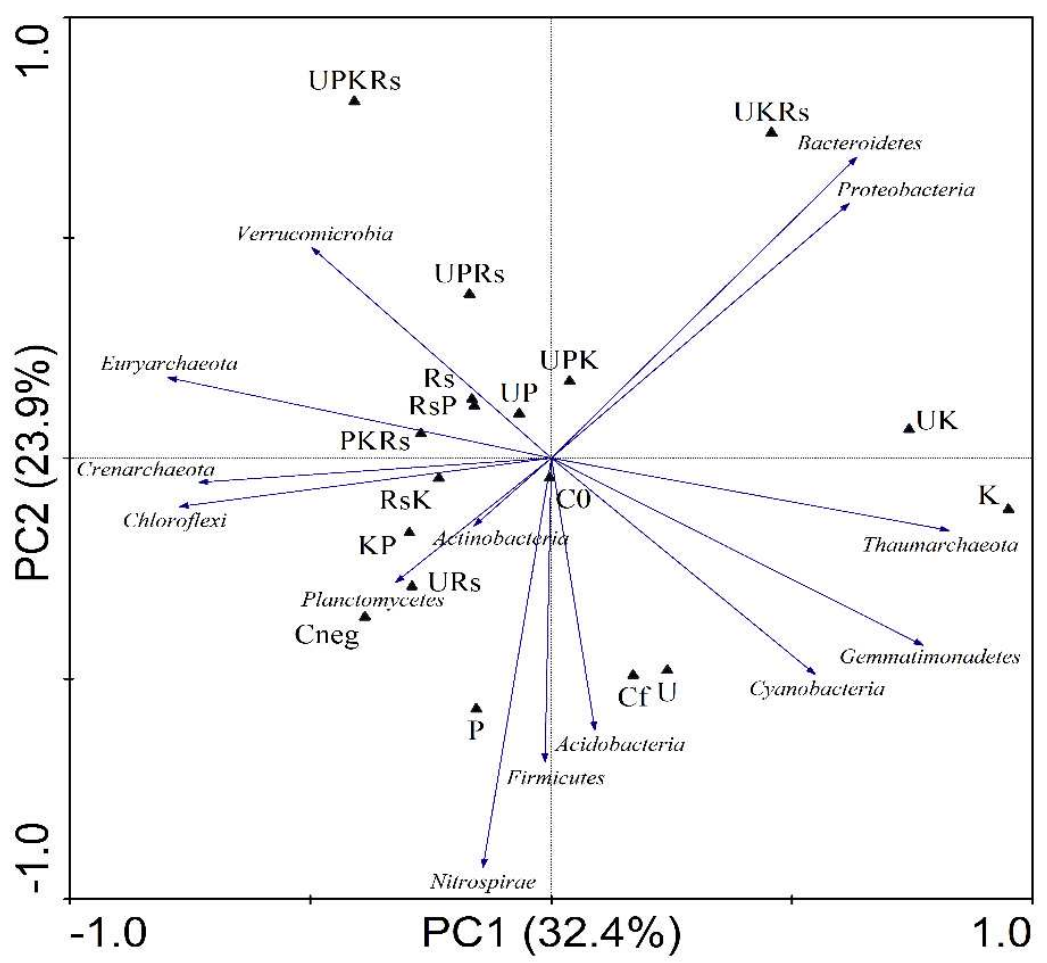

631

632 Fig 4: Principal component analysis (PCA) showing correlation biplot between explanatory soil variables (black 633 triangles) and loadings as bacterial and archaeal phyla (blue lines). The symbols are explained in Table 1. 


\section{Second level (Metabolism)}

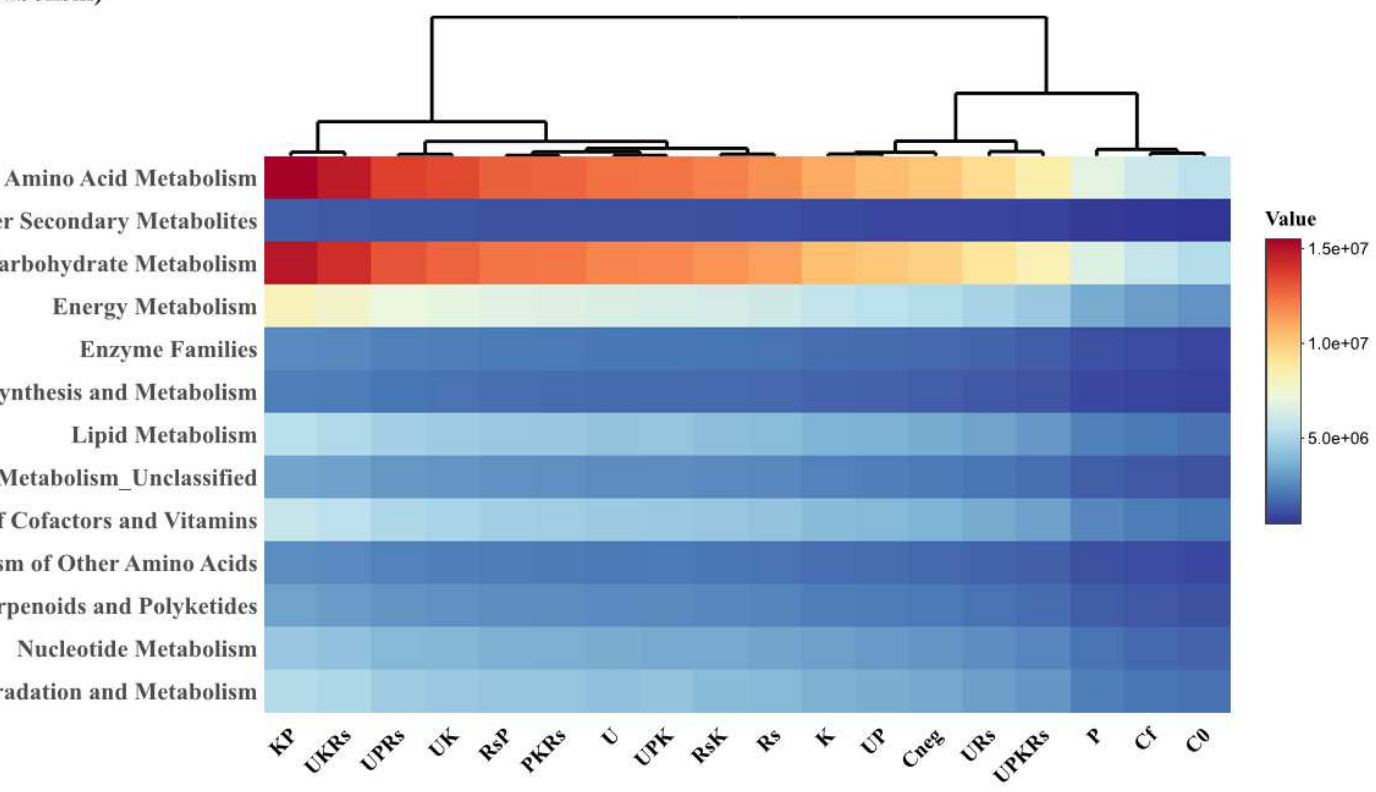

\section{Third level (Energy metabolism)}

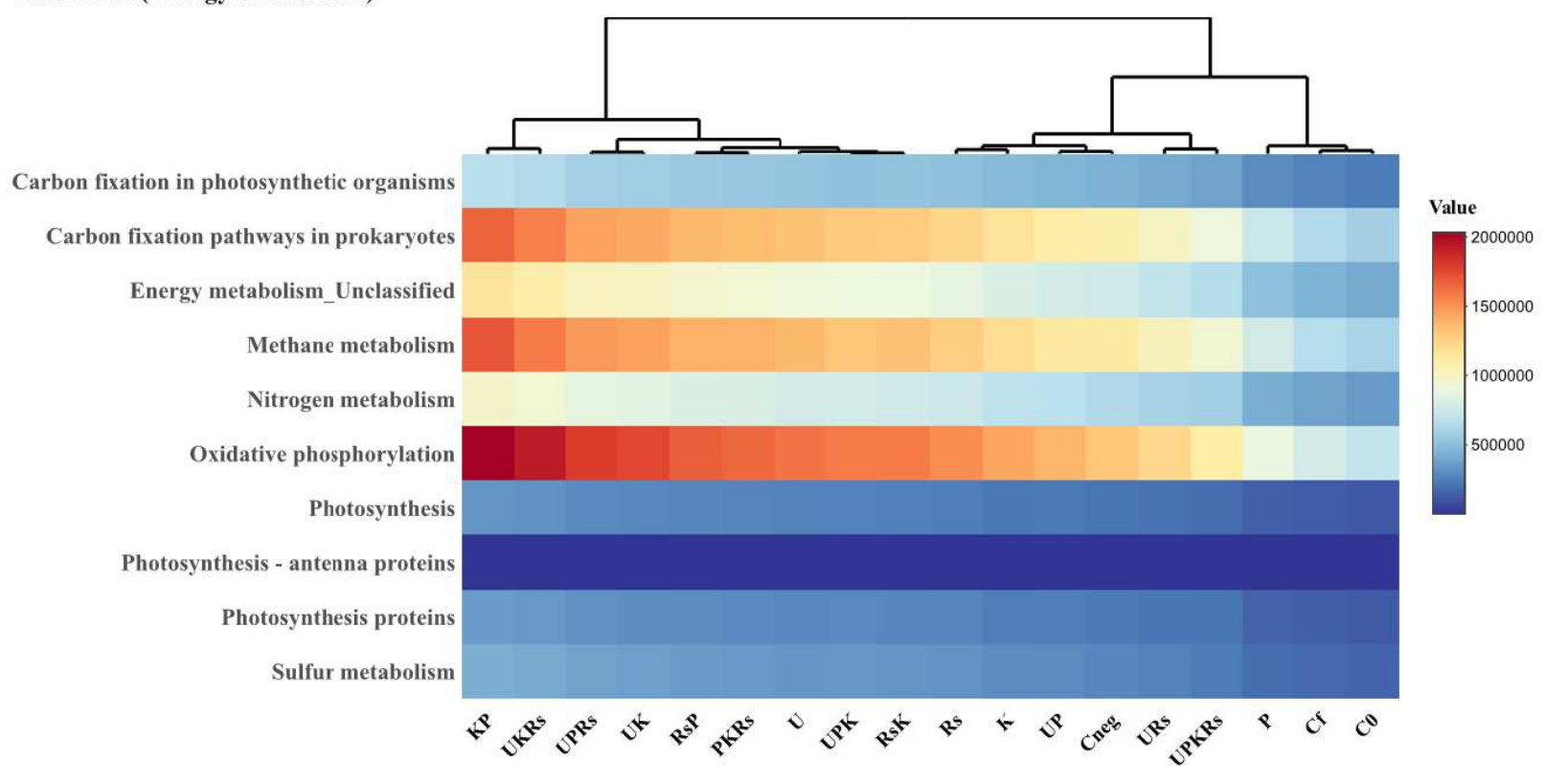

637 level (metabolism) and third level (Energy metabolism). 


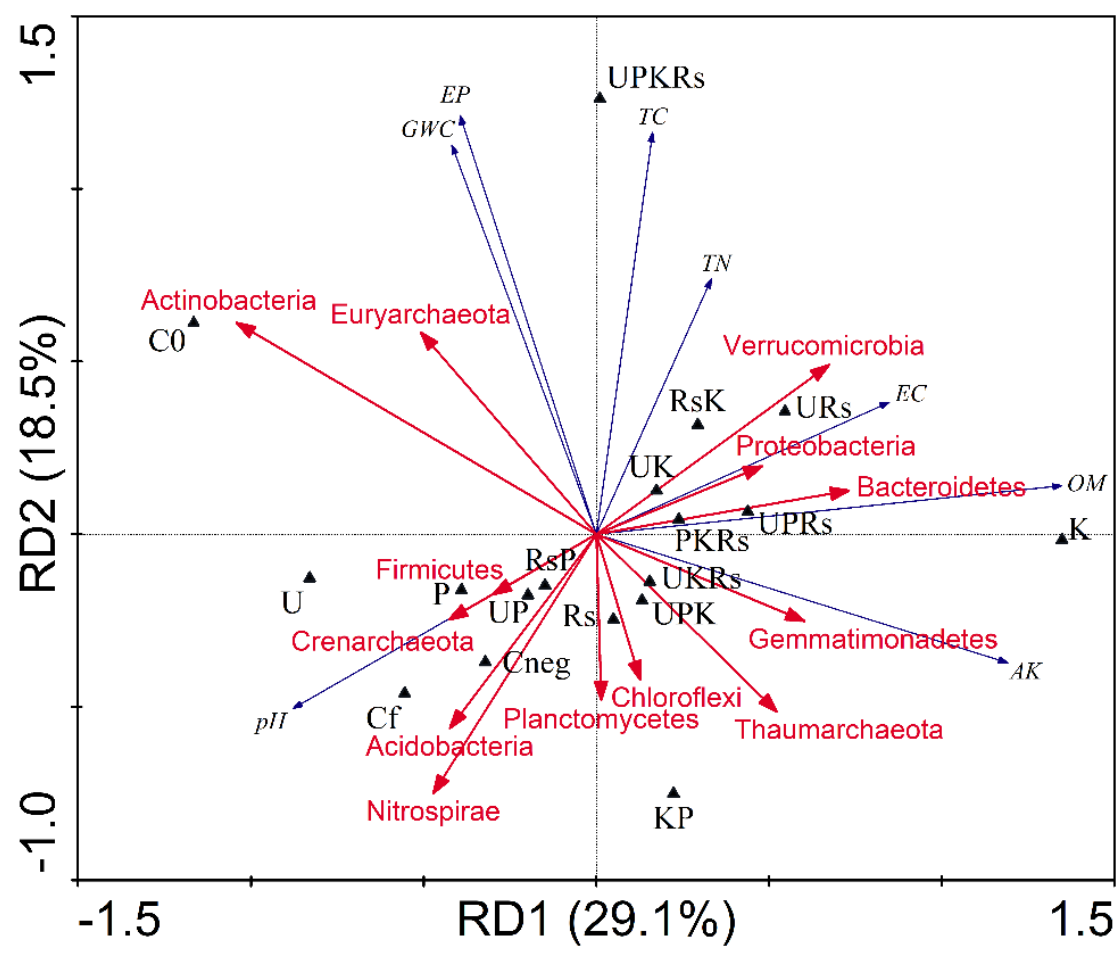

641

642 Fig 1: Redundancy analysis (RDA) of soil microbial community as explained by soil physicochemical parameters.

643

644

645

646

647

648

649

650

651

652 


\section{Supplementary Information (SI)}

654 Table 1: Soil physico-chemical properties of soil against different supplements. Different lowercase represents

655 significant difference.

\begin{tabular}{|c|c|c|c|c|c|c|c|}
\hline Treatment & $p H$ & $\begin{array}{c}E C \\
\mathrm{dS} / \mathrm{cm}\end{array}$ & $\begin{array}{c}T C \\
\%\end{array}$ & $\begin{array}{l}T N \\
\%\end{array}$ & $\begin{array}{c}O M \\
\%\end{array}$ & $\begin{array}{c}A K \\
\mathrm{mg} / \mathrm{kg}\end{array}$ & $\begin{array}{c}E P \\
\mathrm{mg} / \mathrm{kg}\end{array}$ \\
\hline$C_{0}$ & $8.05 \mathrm{~d}$ & $275 a$ & $0.17 \mathrm{a}$ & $1.40 \mathrm{a}$ & $0.73 a$ & $6.50 \mathrm{a}$ & $0.31 \mathrm{a}$ \\
\hline$C_{f}$ & $8.08 \mathrm{de}$ & $283 a$ & $0.16 \mathrm{a}$ & $1.48 \mathrm{a}$ & $0.72 \mathrm{a}$ & $6.40 \mathrm{a}$ & $0.30 \mathrm{a}$ \\
\hline$C_{n e g}$ & $8.28 \mathrm{~g}$ & $446 \mathrm{~d}$ & $0.16 \mathrm{a}$ & $1.44 \mathrm{a}$ & $1.58 \mathrm{~d}$ & $9.40 \mathrm{de}$ & $0.29 \mathrm{a}$ \\
\hline$U$ & $8.20 \mathrm{fg}$ & $342 b c$ & $0.16 \mathrm{a}$ & $1.38 \mathrm{a}$ & $1.15 b$ & $9.60 \mathrm{ef}$ & $0.32 \mathrm{a}$ \\
\hline$P$ & 8.06de & $522 \mathrm{efg}$ & $0.16 \mathrm{a}$ & $1.38 \mathrm{a}$ & $1.80 \mathrm{~g}$ & $8.40 \mathrm{c}$ & $0.31 \mathrm{a}$ \\
\hline K & $7.84 b c$ & $645 \mathrm{i}$ & $0.16 \mathrm{a}$ & $1.46 \mathrm{a}$ & $2.79 \mathrm{k}$ & $13.20 \mathrm{i}$ & $0.30 \mathrm{a}$ \\
\hline$R s$ & 7.82abc & $300 \mathrm{ab}$ & $0.17 \mathrm{a}$ & $1.58 \mathrm{a}$ & $1.64 \mathrm{e}$ & $9.60 \mathrm{ef}$ & $0.28 \mathrm{a}$ \\
\hline$U P$ & $8.02 \mathrm{~d}$ & $504 \mathrm{ef}$ & $0.16 \mathrm{a}$ & $1.50 \mathrm{a}$ & $1.57 \mathrm{~d}$ & $8.70 \mathrm{c}$ & $0.29 \mathrm{a}$ \\
\hline KP & $7.83 b c$ & $338 \mathrm{bc}$ & $0.15 \mathrm{a}$ & $1.35 \mathrm{a}$ & $1.84 \mathrm{~h}$ & $9.50 \mathrm{ef}$ & $0.29 \mathrm{a}$ \\
\hline$R s P$ & $8.04 d$ & $340 \mathrm{bc}$ & $0.18 \mathrm{a}$ & $1.61 \mathrm{a}$ & $1.36 \mathrm{c}$ & $8.80 \mathrm{~cd}$ & $0.30 \mathrm{a}$ \\
\hline$U K$ & $7.82 \mathrm{abc}$ & $602 \mathrm{~h}$ & $0.16 \mathrm{a}$ & $1.38 \mathrm{a}$ & $1.78 \mathrm{f}$ & $9.60 \mathrm{ef}$ & $0.31 \mathrm{a}$ \\
\hline RsK & $8.08 \mathrm{de}$ & $549 \mathrm{~g}$ & $0.17 \mathrm{a}$ & $1.45 \mathrm{a}$ & $1.98 \mathrm{i}$ & $9.50 \mathrm{ef}$ & $0.30 \mathrm{a}$ \\
\hline URs & $7.85 b c$ & $342 \mathrm{bc}$ & $0.18 \mathrm{a}$ & $1.65 \mathrm{a}$ & $2.45 \mathrm{j}$ & $10.10 \mathrm{gh}$ & $0.29 \mathrm{a}$ \\
\hline$U P K$ & $7.75 \mathrm{abc}$ & $544 \mathrm{fg}$ & $0.17 \mathrm{a}$ & $1.47 \mathrm{a}$ & $1.99 \mathrm{i}$ & $10.00 \mathrm{efg}$ & $0.28 \mathrm{a}$ \\
\hline UPRs & $7.85 b c$ & $523 \mathrm{efg}$ & $0.17 \mathrm{a}$ & $1.53 \mathrm{a}$ & $1.75 f$ & $10.60 \mathrm{~h}$ & $0.29 \mathrm{a}$ \\
\hline UKRs & $7.88 \mathrm{c}$ & $346 c$ & $0.16 \mathrm{a}$ & $1.45 \mathrm{a}$ & $1.77 \mathrm{f}$ & $9.40 \mathrm{de}$ & $0.28 \mathrm{a}$ \\
\hline PKRs & $7.68 \mathrm{a}$ & $482 \mathrm{de}$ & $0.15 \mathrm{a}$ & $1.35 \mathrm{a}$ & $1.82 \mathrm{~g}$ & $8.50 \mathrm{c}$ & $0.30 \mathrm{a}$ \\
\hline UPKRs & 7.72ab & $504 \mathrm{ef}$ & $0.18 \mathrm{a}$ & $1.64 \mathrm{a}$ & $1.76 \mathrm{f}$ & $7.60 \mathrm{~b}$ & $0.33 \mathrm{a}$ \\
\hline
\end{tabular}

656 
Figures

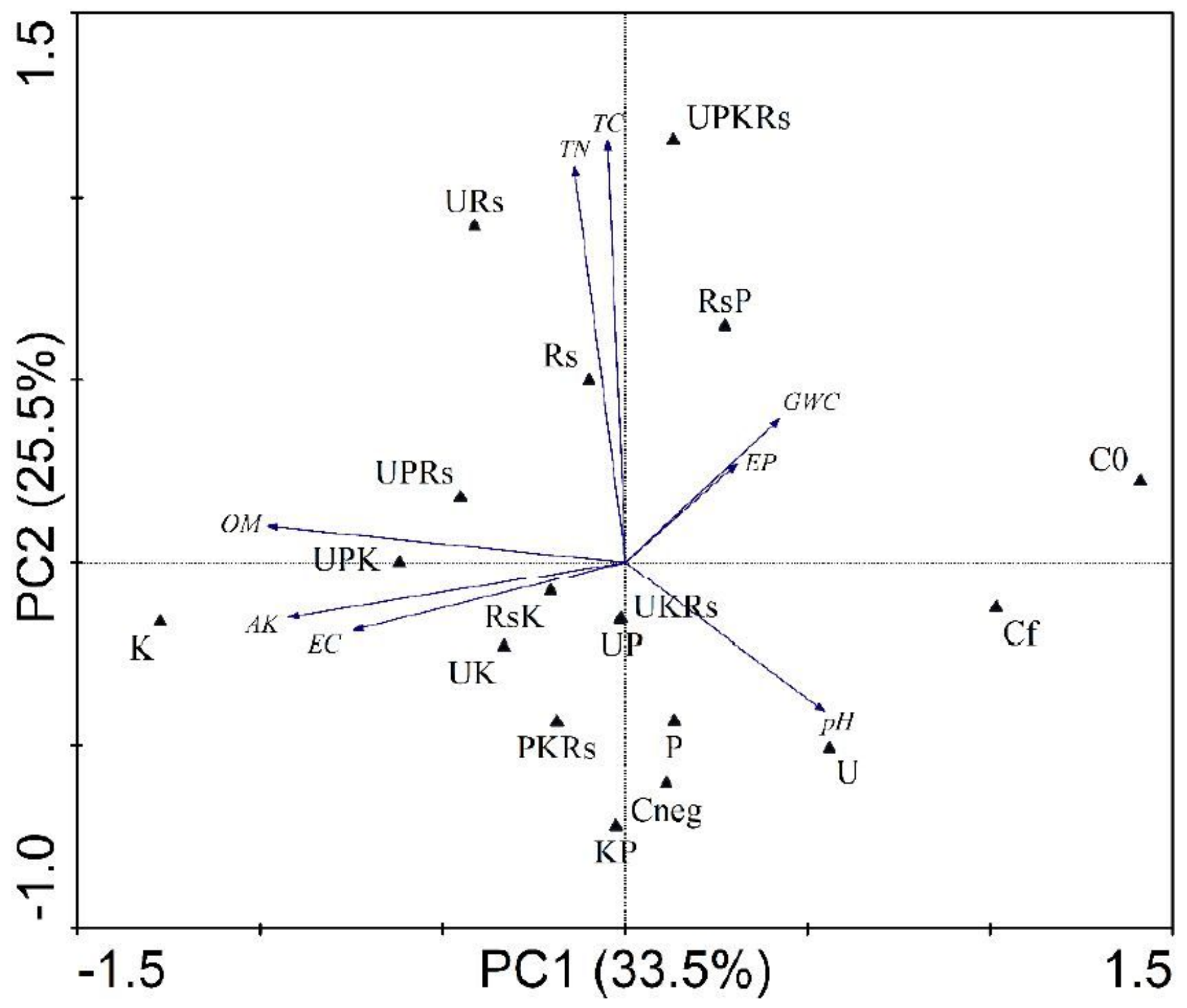

Figure 1

Principal component analysis (PCA) showing correlation biplot between explanatory soil variables (black triangles) and loadings (blue lines). The symbols denote samples and are explained in Table 1. 


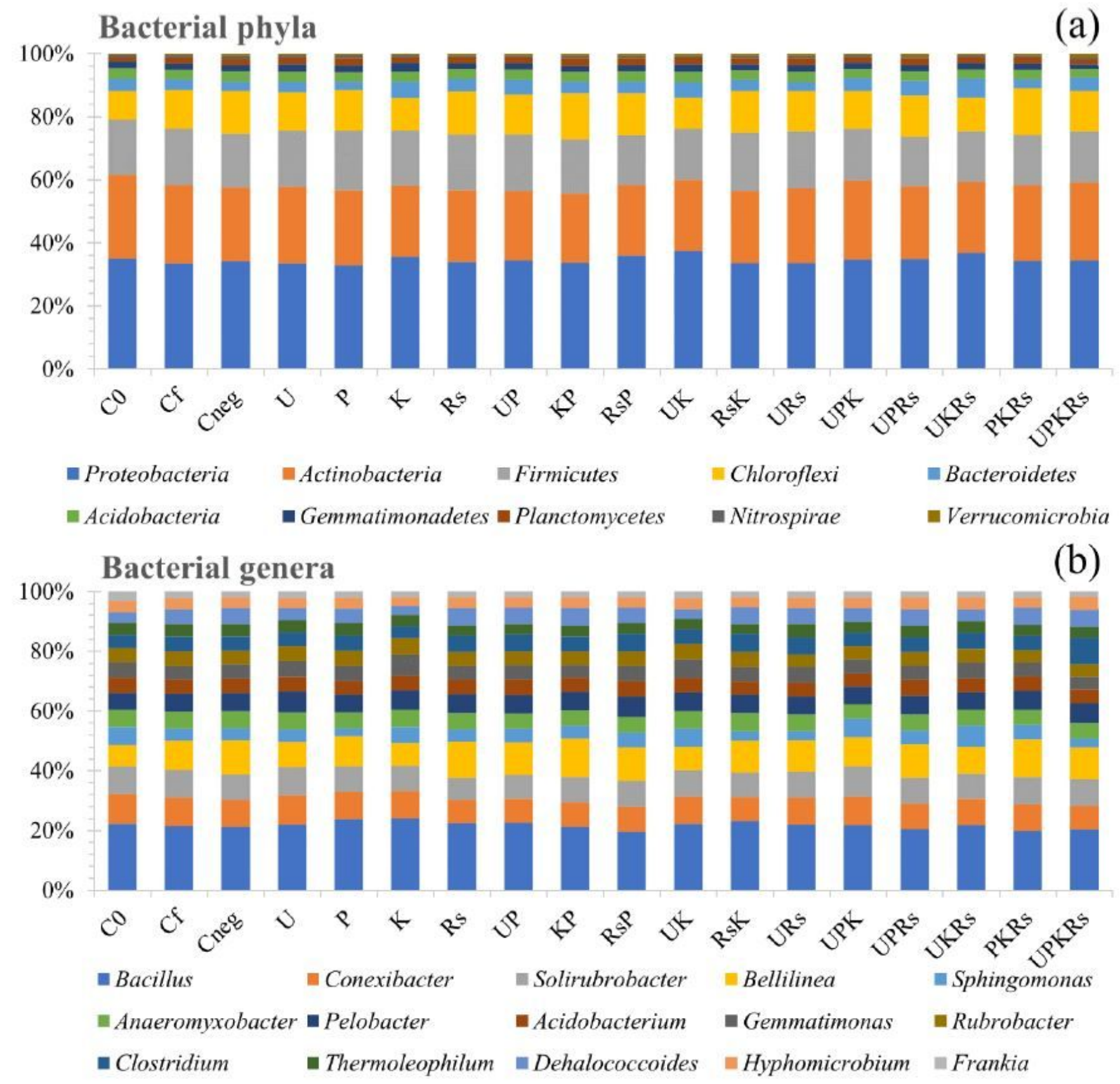

Figure 2

Relative abundance of major bacterial phyla that accounts for $\approx 99 \%$ of bacterial community (a) and genera (b) in all treatments. 


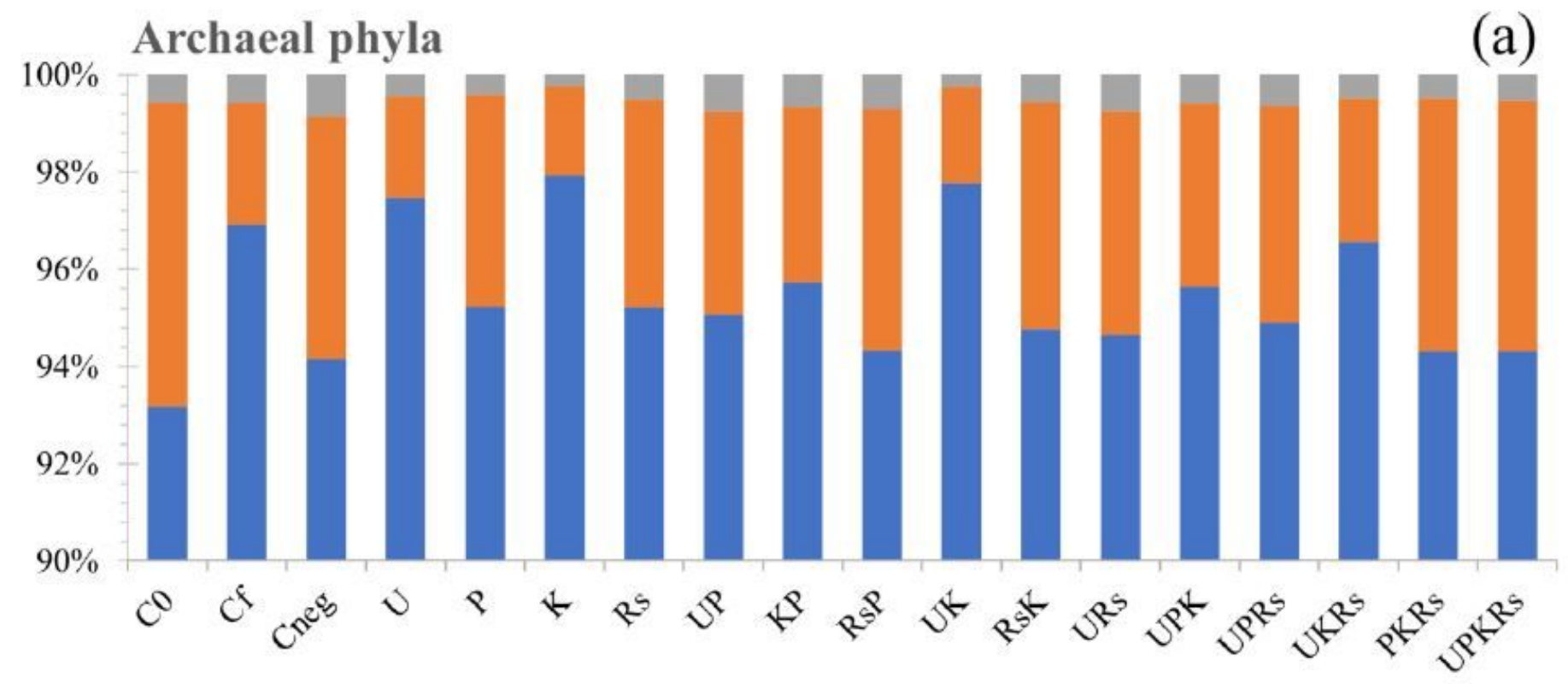

= Thaumarchaeota =Euryarchaeota = Crenarchaeota

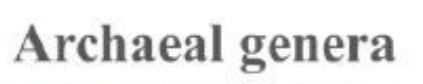

(b)

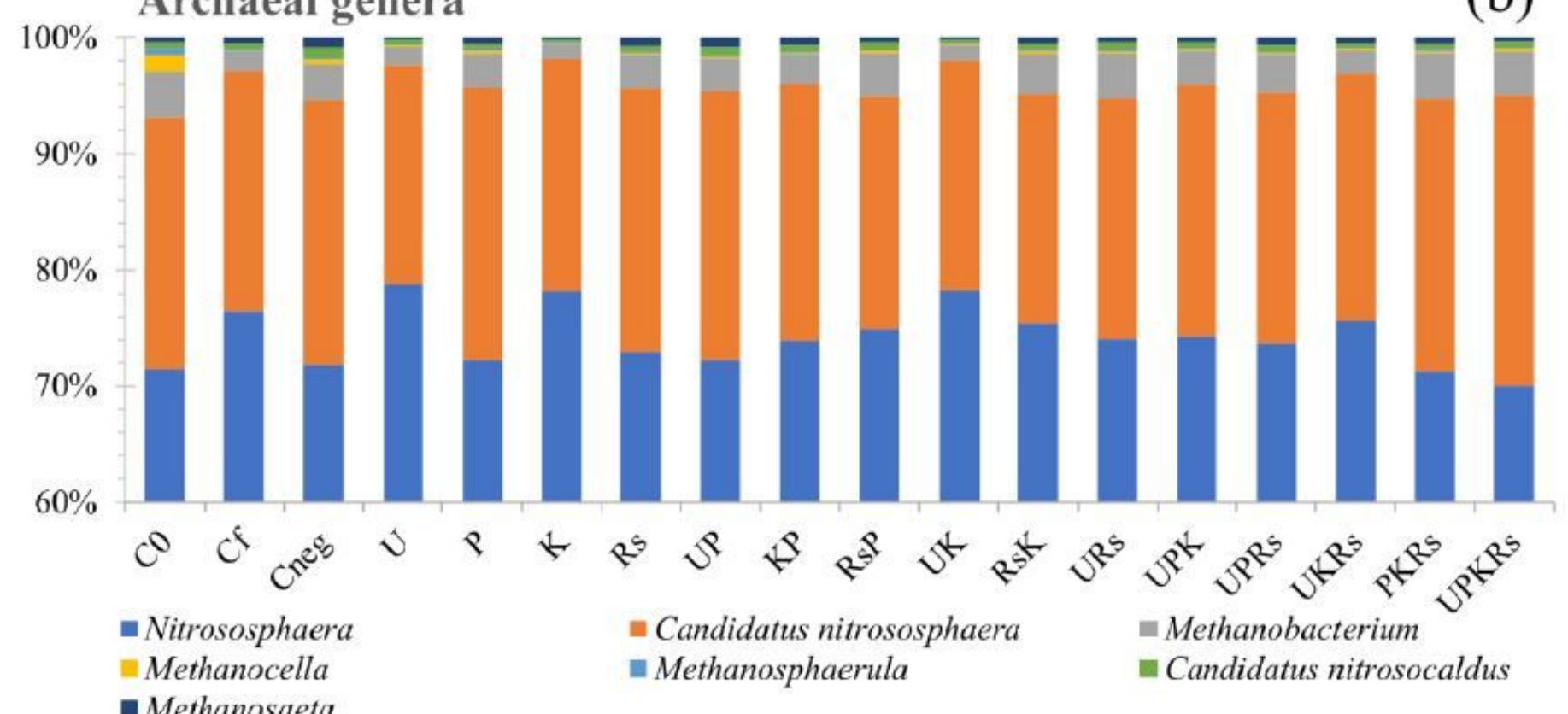

Figure 3

Relative abundance of archaeal phyla and genera in all samples. 


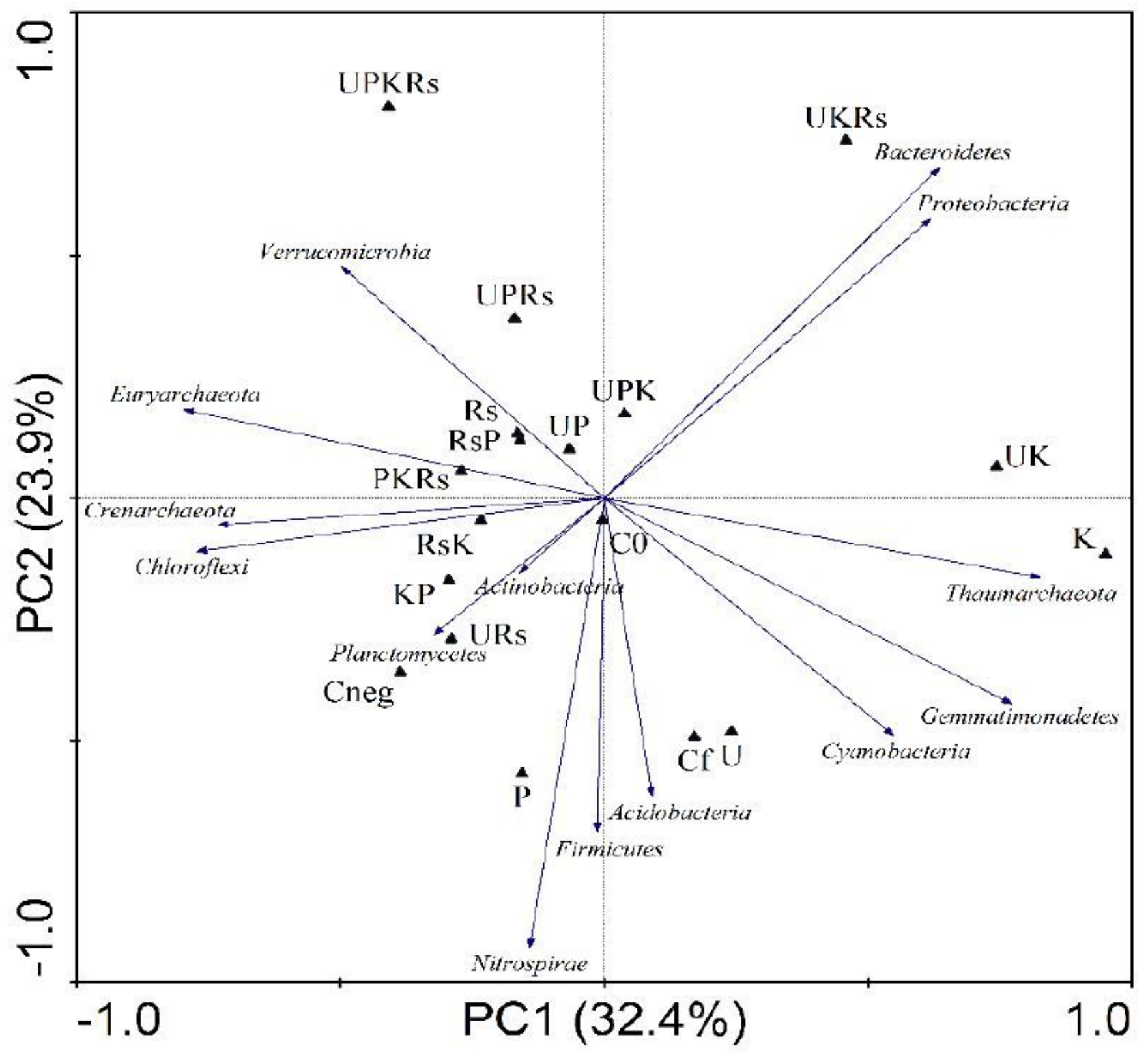

Figure 4

Principal component analysis (PCA) showing correlation biplot between explanatory soil variables (black triangles) and loadings as bacterial and archaeal phyla (blue lines). The symbols are explained in Table 1. 


\section{Second level (Metabolism)}

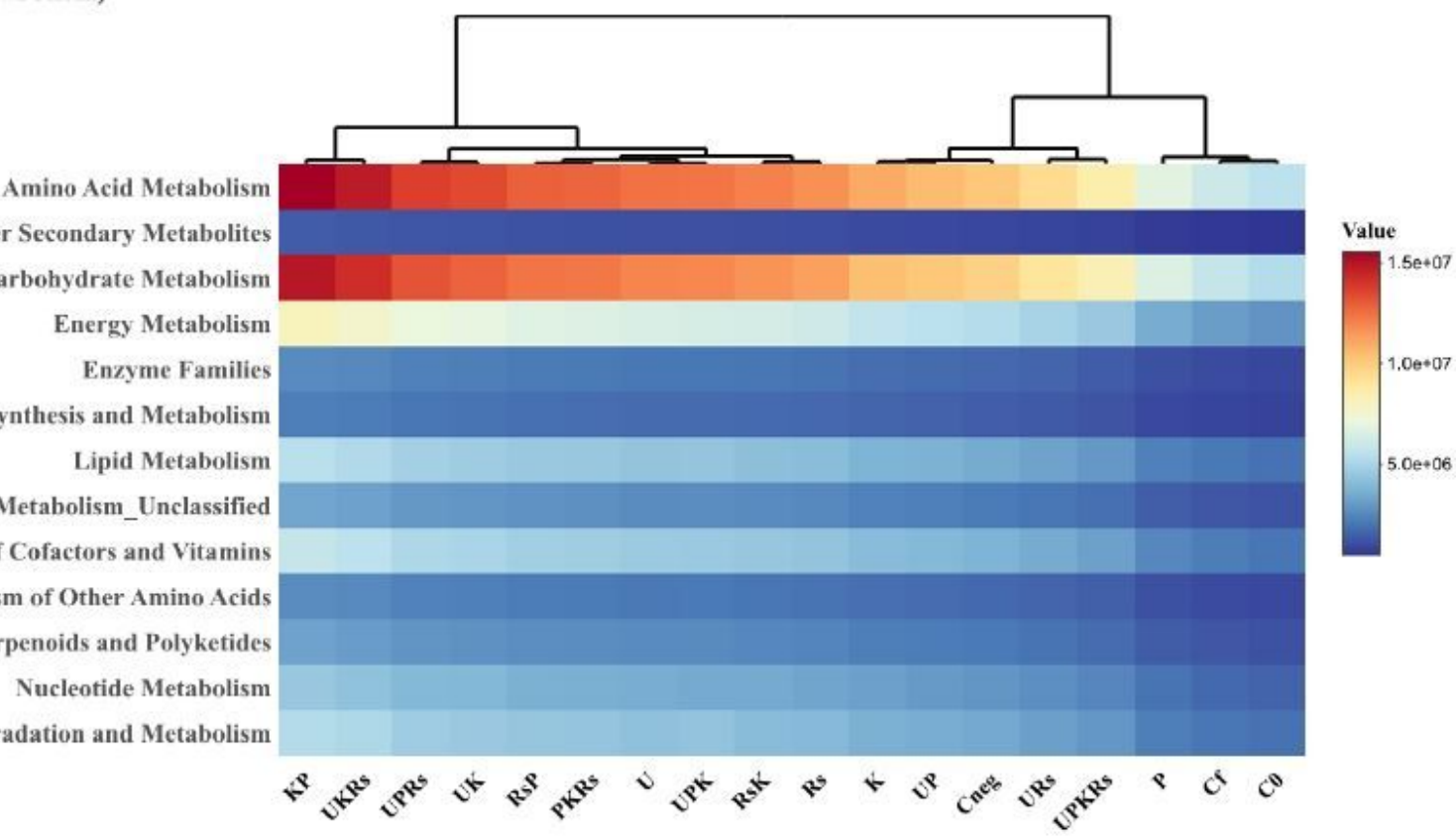

Third level (Energy metabolism)

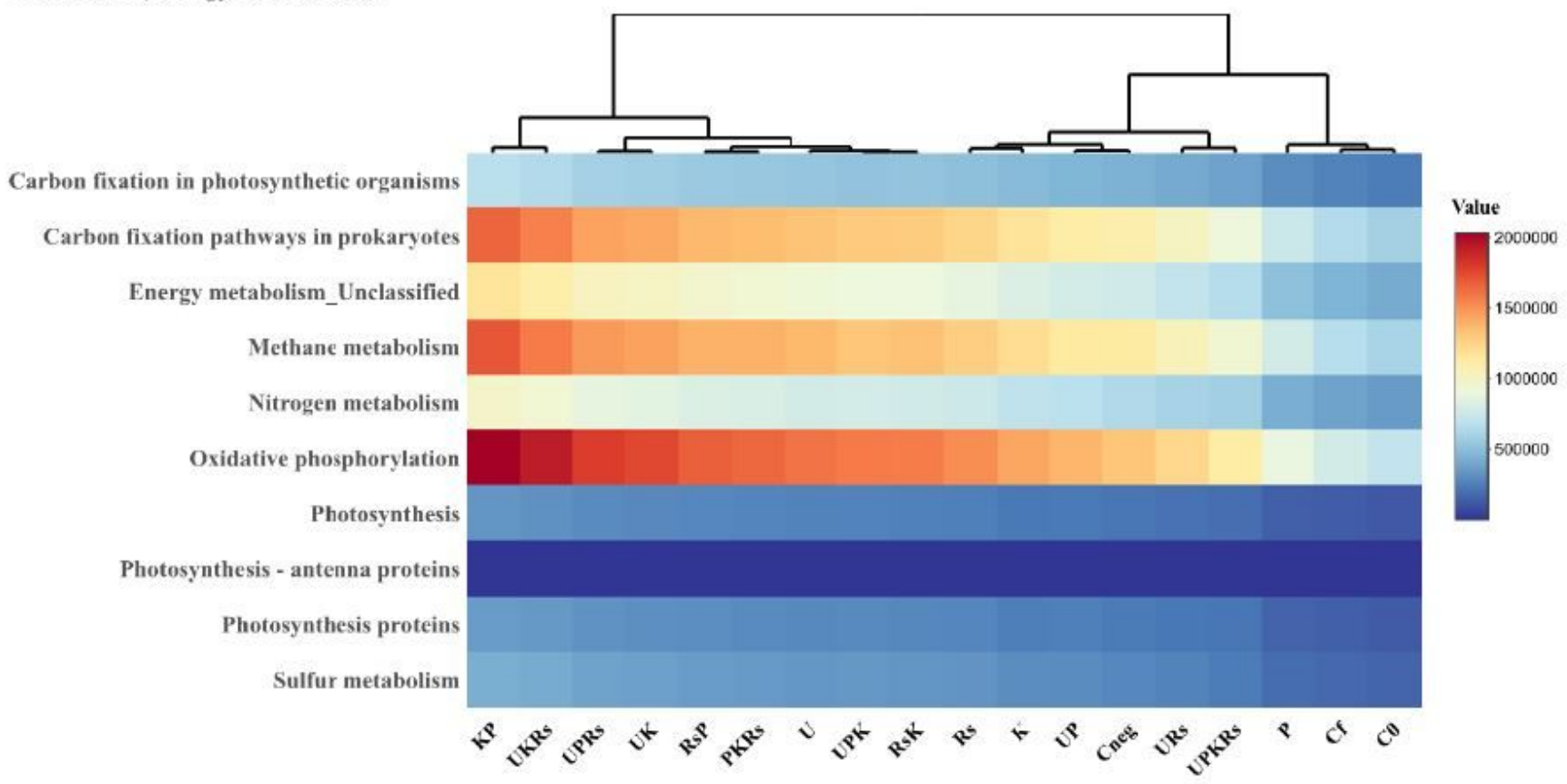

\section{Figure 5}

Heat map demonstrating PICRUSt derived hierarchical clustering of predicted functional profiles at second level (metabolism) and third level (Energy metabolism). 


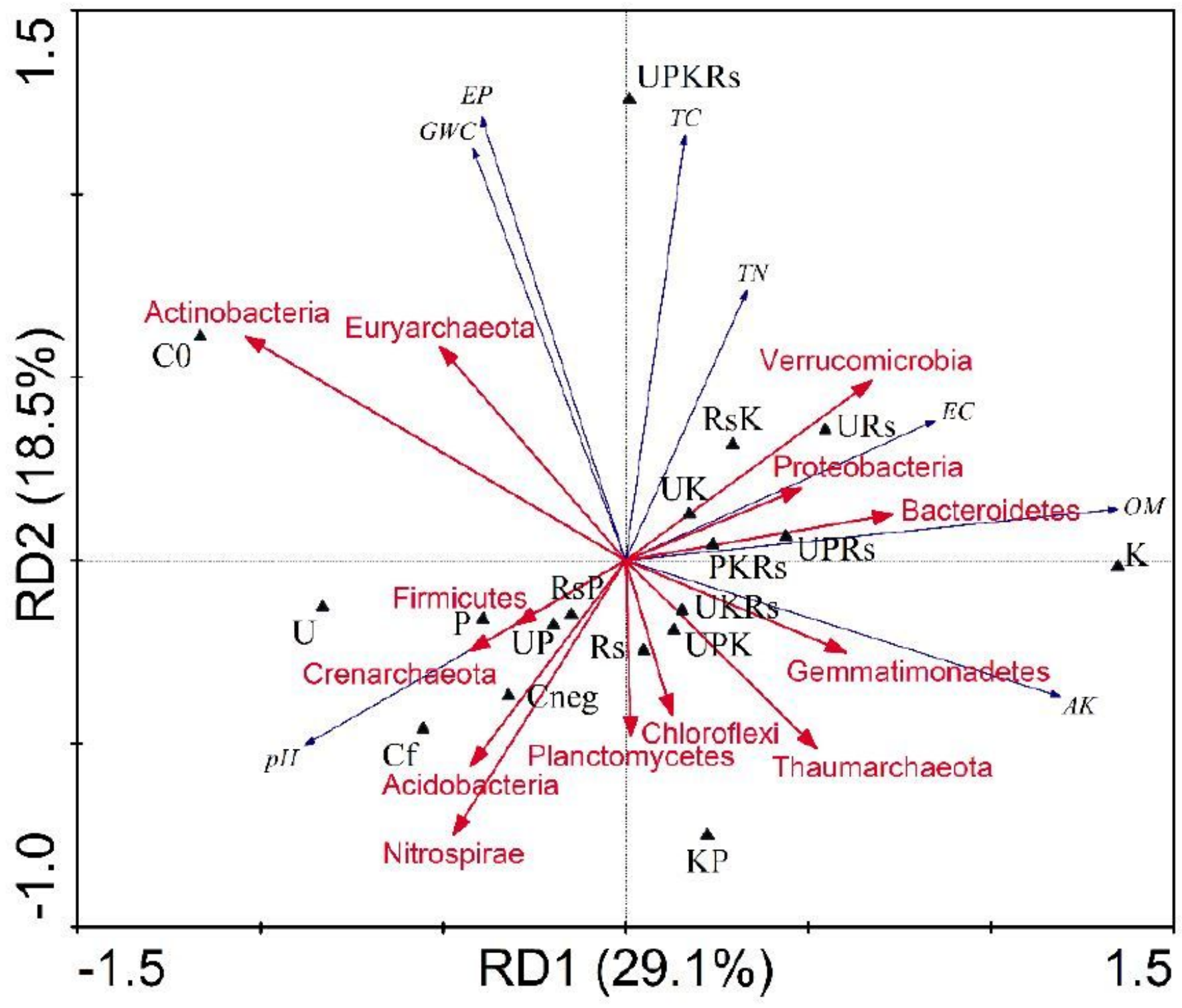

Figure 6

Redundancy analysis (RDA) of soil microbial community as explained by soil physicochemical parameters.

\section{Supplementary Files}

This is a list of supplementary files associated with this preprint. Click to download.

- graphicsabstract.jpg 